
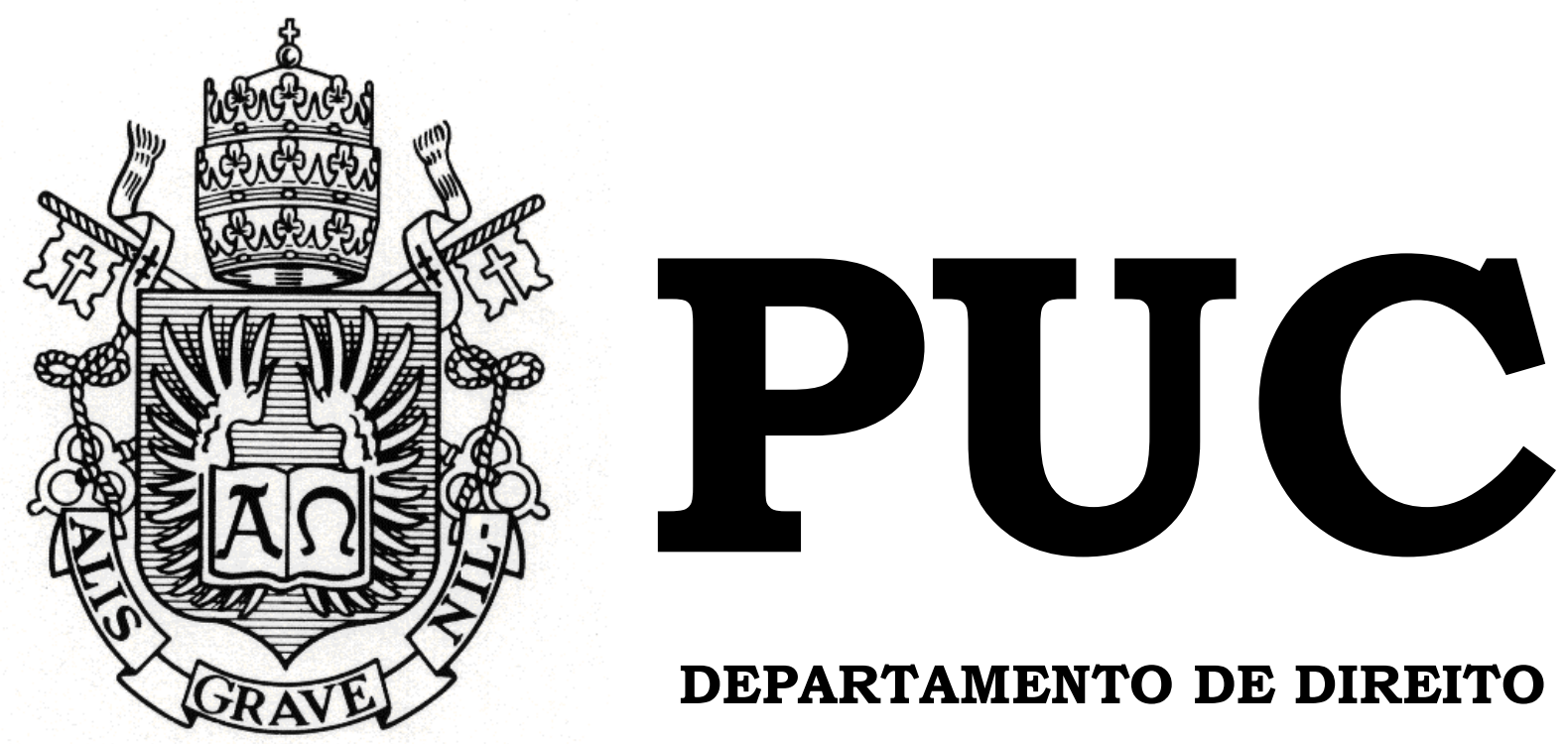

DEPARTAMENTO DE DIREITO

Direito à Busca da Felicidade no âmbito da comunidade LGBT+ e as ações afirmativas para a garantia desse direito

por

DIOGO ELIAS GOMES DA SILVA

ORIENTADORA: Regina Coeli Lisboa Soares

2019.2

PONTIFÍCIA UNIVERSIDADE CATÓLICA DO RIO DE JANEIRO

RUA MARQUÊS DE SÃO VICENTE, 225 - CEP 22453-900

RIO DE JANEIRO - BRASIL 


\section{Direito à Busca da Felicidade no âmbito da comunidade LGBT+ $e$ as ações afirmativas para a garantia desse direito}

por

DIOGO ELIAS GOMES DA SILVA

Monografia apresentada ao Departamento de Direito da Pontificia Universidade Católica do Rio de Janeiro (PUC-Rio) para a obtenção do Título de Bacharel em Direito.

Orientador(a): Regina Coeli Lisboa Soares 


\section{Agradecimentos}

Acredito que uma vida bem vivida é quando temos pessoas que trilham os caminhos conjuntamente com a gente. Por isso, acredito que, realmente, estou vivendo feliz, porque sou cercado de pessoas que amo e que foram muito importantes para eu chegar aonde cheguei e por terem me dado o apoio que eu precisava durante a escrita dessa monografia e para a conclusão do curso de Direito.

Primeiramente, devo agradecer aos meus pais, Marlinete e Jorge, por acreditarem que eu conseguiria cursar uma faculdade renomada de Direito e por estarem sempre ao meu lado independentemente da situação. O tema dessa monografia é muito importante para mim, pois estou inserido na realidade que trato ao longo desse trabalho. Sou gay e, em muitos momentos, reflito se sou feliz e percebo que não tenho motivos para não ser, porque tenho o apoio das pessoas que mais amo e o amor deles me fez acreditar em mim e na minha capacidade de terminar esse curso.

Agradeço à minha família como um todo por me amar incondicionalmente e estar sempre ao meu lado em qualquer situação. Sem ela eu não teria conseguido a força que tenho para seguir, assim como a crença de que conseguiria terminar esse curso.

Aos meus amigos, em especial, João Felipe, Juan Cosme, Bruno Campos, Rodolfo de Oliveira e Diego Sahione, agradeço por estarem sempre dispostos a ouvir minhas reclamações em relação ao desenvolvimento do presente trabalho e por me ajudarem a aliviar o estresse em momentos muito agradáveis e que me ajudaram a relaxar.

Às minhas amigas da faculdade, principalmente, Rosane Azevedo, Letícia Castro, Camilla Góes, Julia Lemos, Carolina Garrido e Mariana Temido, agradeço por terem trilhado o caminho da graduação comigo, do início ao fim. Nos momentos que pensei em desistir, elas foram essenciais para que eu não desacreditasse em mim e conseguisse me formar.

Aos mestres que tive a honra de ter as minhas aulas, agradeço pelas aulas e pelo conteúdo aprendido. Devo muito a todos eles por terem me 
proporcionado os instrumentos necessários para que eu tivesse um bom resultado na prova da $\mathrm{OAB}$ e, com a conclusão do curso, já poder dizer a todos que sou advogado.

Por fim, à minha querida orientadora, Regina Coeli, agradeço a paciência e por ter me dado todos os instrumentos necessários para o desenvolvimento dessa monografia. Obrigado por ter acreditado na minha ideia para esse trabalho e por ser essa mulher que eu admiro e respeito. 


\section{Resumo}

O presente trabalho tem, precipuamente, o intuito de analisar a força normativa desse conceito ao tratar essa busca como um direito fundamental atrelado a dois importantes princípios constitucionais: a igualdade e a dignidade da pessoa humana.

A partir disso, o direito à busca da felicidade será discutido no âmbito da comunidade LGBT+, tratando da história do movimento no Brasil e de algumas demandas que foram conquistadas desde o seu início, como a união homoafetiva, o casamento igualitário e a criminalização da homofobia.

Em seguida, tratar-se-á do direito à busca da felicidade na sua essência, assim como os efeitos gerados a partir dele para a comunidade LGBT+. Isso será realizado ao se trazer breves apontamentos do que seria a felicidade na filosofia, expondo as visões de grandes filósofos, como Sócrates, Platão e Aristóteles. Será debatido também algumas características e a importância do termo, assim como a previsão normativa e os efeitos do mesmo na seara da comunidade LGBT+, a partir da análise de algumas decisões do STF, nas quais esse direito foi mencionado.

Por fim, será abordado o tema das ações afirmativas na perspectiva de sua necessidade, para que sejam igualados os direitos homossexuais com os heterossexuais. Além disso, tratar-se-á de algumas demandas de pessoas trans, por acreditar que essa parcela da comunidade LGBT+ é a que mais sofre com preconceito e discriminação.

Palavras-chave: direito à busca da felicidade, direitos fundamentais, dignidade da pessoa humana, igualdade, ações afirmativas, LGBT+, transgêneros. 


\section{Resumen}

Este trabajo tiene, esencialmente, el objetivo de analisar la fuerza normativa de este concepto al tratar esa búsqueda como un derecho fundamental asociado a dos importantes principios constitucionales: la igualdad y la dignidad de la persona humana.

A partir de esto, el derecho a la búsqueda de la felicidad será discutido en el ámbito de la comunidad LGBT+, tratando de la historia del movimiento en Brasil y de algunas demandas que fueron conquistadas desde su principio, como la unión homoafectiva, o casamiento igualitario y la criminalización de la homofobia.

En seguida, se tratará del derecho a la búsqueda de la felicidad en su esencia, así como los efectos generados a partir de él para a comunidade LGBT+. Esto se realizará al presentar breves apuntes de lo que sería la felicidad en la filosofía, exponiendo visiones de grandes filósofos, como Sócrates, Platão y Aristóteles. Será debatido también algunas características y la importancia del término, así como la previsión normativa y sus efectos en el área de interés de la comunidad LGBT+ a partir de la análisis de algunas decisiones del STF, en las cuales ese derecho ha sido mencionado.

Por fin, será abordado el tema de las acciones afirmativas en la perspectiva de su necesidad para que sean igualados los derechos homosexuales con los heterosexuales. Además, se tratará de algunas demandas de personas trans por creer que esa parcela de la comunidad LGBT+ es la que más sufre con el prejuicio y la discriminación.

Palabras clave: derecho a la búsqueda de la felicidad, derechos fundamentales, dignidad de la persona humana, igualdad, acciones afirmativas, LGBT+, transgéneros. 


\section{SUMÁRIO}

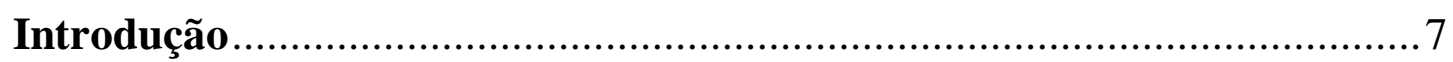

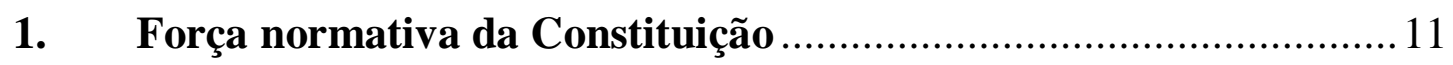

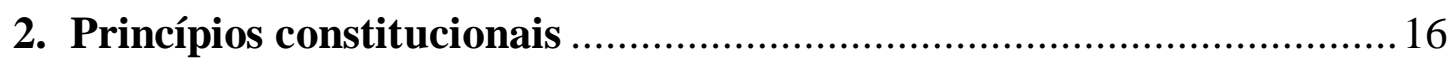

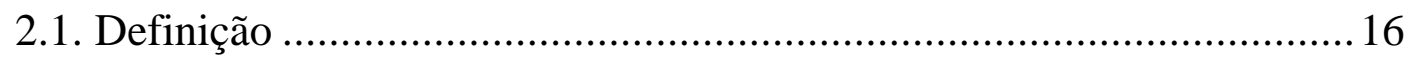

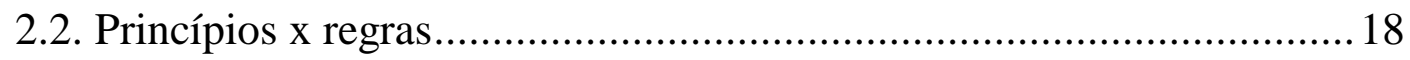

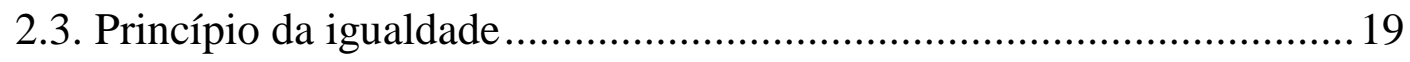

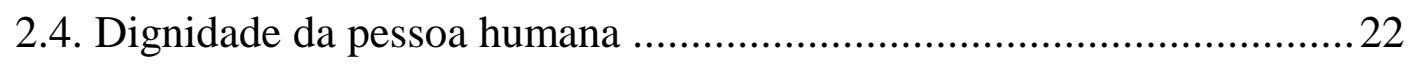

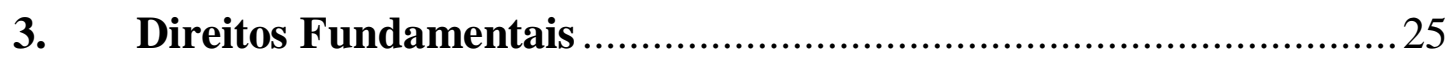

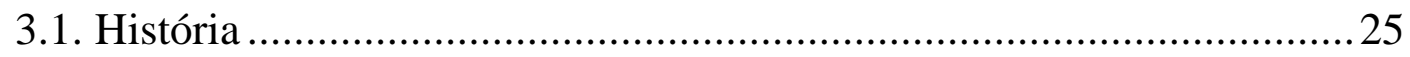

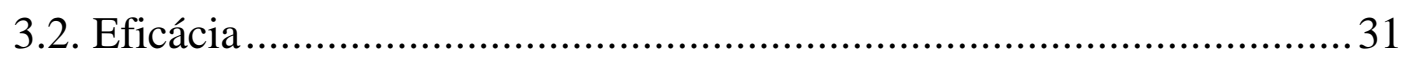

4. Movimento LGBT+ e demandas conquistadas ……................................ 35

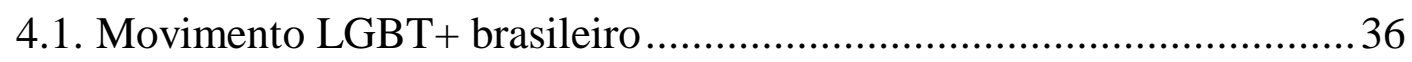

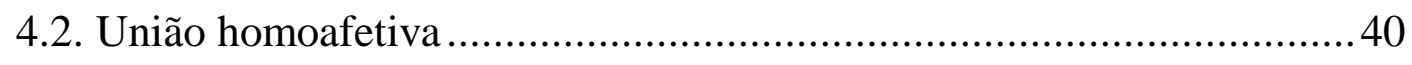

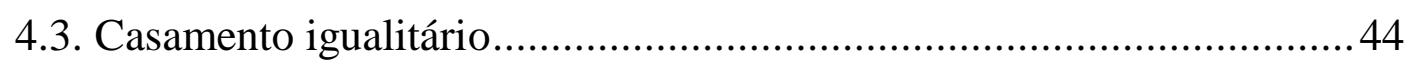

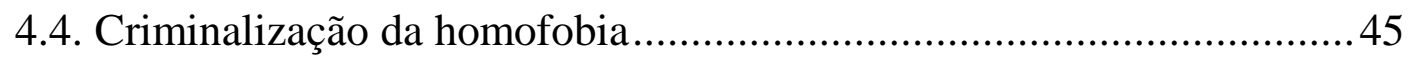

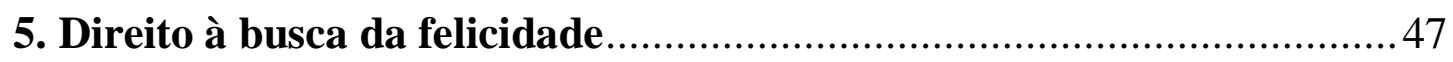

5.1. Breves apontamentos sobre felicidade na filosofia ..............................4 47

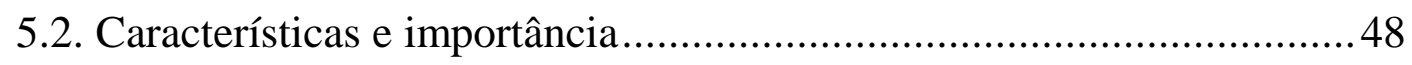

5.3. Previsão e efeitos na comunidade LGBT+...........................................49

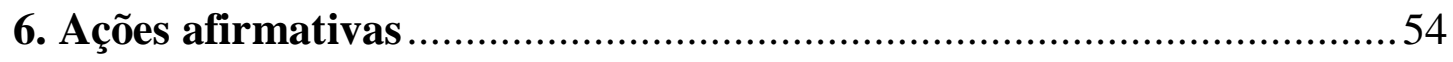

6.1. Breve abertura: noções e conceito ……….......................................54

6.2. Panorama das ações afirmativas para a comunidade LGBT + ...............57

6.2.1. Demandas de pessoas trans.....................................58

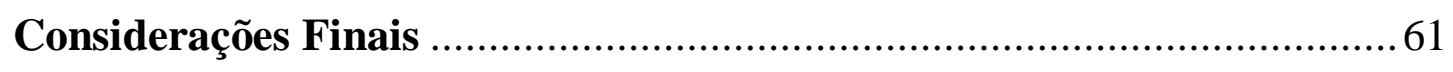

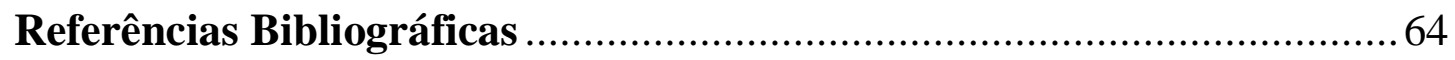




\section{Introdução}

O presente trabalho trata do direito à busca da felicidade de uma minoria composta pela população LGBT+e as ações afirmativas voltadas para essas pessoas, possibilitando, assim, que elas tenham esse seu direito fundamental garantido.

É de suma importância tratar do tema em questão no atual contexto em que se encontra o país, visto que foi eleito um presidente que se autodeclara homofóbico e que teve grande parte de sua campanha para a presidência baseada em comentários e propostas contra a comunidade LGBT+. Essa parte da população brasileira tinha cada vez mais direitos reconhecidos. Contudo, com a eleição do novo presidente, existe o risco de direitos adquiridos serem retirados e, além disso, de o preconceito aumentar ou ser até mesmo validado.

Dessa forma, é imprescindível que se discuta essa questão e que se procurem alternativas e soluções para que a comunidade LGBT+ seja tratada normativamente e de fato igual à população heterossexual. Dentre os direitos a serem garantidos a essa minoria encontra-se o direito à busca da felicidade, e até pode parecer pífio para alguns que este precise ser protegido, mas no âmbito homossexual ele é esquecido de forma recorrente.

A partir disso, o tema em questão será desenvolvido expondo, primeiramente, a força normativa que a Constituição Federal possui. Isso será feito realizando-se uma análise sobre as ideias propostas por Ferdinand Lassalle e Konrad Hesse, demonstrando que compartilhamos do que fora defendido por Hesse, ou seja, que o Direito Constitucional e a Constituição possuem certo grau de independência em relação à realidade político-social vigente e que, sendo assim, a Constituição jurídica não passa apenas de um pedaço de papel, como trata Lassalle em sua obra.

Em seguida, irei discorrer sobre o que são os princípios constitucionais, realizando a distinção entre estes e as regras, tratando de sete critérios que são 
mais utilizados pela doutrina com esse intuito. Estes critérios são baseados na obra de Ana Paula de Barcellos. Também será esmiuçado o princípio da igualdade, distinguindo suas duas vertentes: formal e material. A partir disso, torna-se nítido que ao tratar das ações afirmativas voltadas à comunidade LGBT+, faz-se necessária a concepção de igualdade material, pois é assim que será possível, realmente, a igualdade entre os direitos dos homossexuais e dos heterossexuais, resultando numa sociedade mais justa. Além da igualdade, será explicado o princípio da dignidade humana, que é um dos pilares do nosso ordenamento constitucional e de suma importância para que as demandas LGBT+ sejam garantidas, visto que aqueles que fazem parte dessa comunidade são humanos, assim como os heterossexuais e, portanto, são merecedores de direitos iguais e de não sofrerem com condutas discriminatórias que atentem contra a sua dignidade.

Depois falarei da história dos direitos fundamentais, demonstrando como ocorreu o nascimento até a sua efetiva positivação, juntamente com a eficácia desses direitos. Nesse momento, é ressaltada a importância desses direitos e como eles foram aumentando quantitativamente e adquirindo cada vez mais destaque tanto no nosso país quanto em muitos outros ao redor do globo. Aqui se realiza uma abertura à proposta de que o direito à busca da felicidade é um direito fundamental e, dessa forma, deve ser assegurado pelo Estado.

Tratarei, além dos temas citados, da história do movimento LGBT+, especificamente do brasileiro, até os dias atuais e algumas de suas demandas conquistadas. A história do movimento no Brasil vai ser estudada a partir da teoria de Regina Facchini, na qual este movimento pode ser dividido em três ondas sucessivas. Em relação às demandas que foram conquistadas, abordo três delas que são: a união homoafetiva, assegurada pela decisão no julgamento em conjunto da ADI 4277 e da ADPF 132; o casamento igualitário, possível pela Resolução 175 do Conselho Nacional de Justiça; e, por fim, a 
criminalização da homofobia, a partir do julgamento da ADO 26, enquadrando homofobia e transfobia como "racismo social". Essas vitórias da comunidade LGBT+ são importantes para demonstrar que os grupos que compõem a sigla merecem ter seu direito à busca da felicidade assegurado.

Em conexão com o capítulo anterior, trato, em seguida, do direito à busca da felicidade. Primeiramente, realizo um breve panorama de como alguns filósofos conceituavam o que seria a felicidade. Além disso, exponho algumas características desse direito e a sua importância, demonstrando que há o direito à felicidade, que se trata de um dever positivo do Estado e o direito à busca da felicidade, que é o dever negativo do Estado e dos particulares de não intervirem na busca por desejos e preferências legítimas dos indivíduos. Ainda, nesse capítulo, abordo a previsão e os efeitos do direito à busca da felicidade na comunidade LGBT+, inclusive por meio da PEC da Felicidade e de algumas decisões que tiveram esse direito como fundamento.

Por fim, discorrerei sobre as ações afirmativas, expondo, primeiramente, o que seria uma ação afirmativa e, a partir disso, algumas noções a respeito da mesma. Em seguida, trato do panorama dessas medidas em relação à comunidade LGBT+ e de algumas demandas de pessoas trans, que costumam ser a parcela dessa comunidade que mais sofre com preconceito e discriminação. Assim, é nítida a necessidade da aplicação de políticas de ações afirmativas voltadas à comunidade LGBT+, mais especificamente direcionadas à parcela composta por pessoas trans e travestis.

Espera-se que o presente trabalho possa trazer contribuições para o conhecimento humano, servindo para que as pessoas percebam que não há mais espaço para preconceito e discriminação na sociedade atual. Somos muito diferentes uns dos outros, contudo compartilhamos a nossa identidade humana e, portanto, devemos todos ter garantido o direito à dignidade da pessoa humana. Sob essa ótica, as demandas da comunidade LGBT+ devem ser 
acatadas, tendo por fundamento o direito à busca da felicidade. Somente assim será possível que tenhamos uma sociedade mais igual e justa no futuro. 


\section{Força normativa da Constituição}

Segundo a tese fundamental de Ferdinand Lassale, questões constitucionais não devem ser tratadas como questões jurídicas, e sim como questões políticas. Isso porque a Constituição de um país exprime as relações de poder nele dominantes, como, por exemplo, o poder militar, que é representado pelos latifundiários e o poder intelectual, representado pela consciência e pela cultura gerais. Segundo Lassale,

As relações fáticas resultantes da conjugação desses fatores constituem a força ativa determinante das leis e das instituições da sociedade, fazendo com que estas expressem, tão somente, a correlação de forças que resulta dos fatores reais de poder. Esses fatores reais do poder formam a Constituição real do país (HESSE, 1991, p. 9).

Dessa forma, Lassale expõe sua tese de que a Constituição jurídica é apenas um pedaço de papel e que sua capacidade tanto de regular quanto de motivar depende da sua compatibilidade com a Constituição real.

Tendo em vista a concepção de Lassalle, o Direito Constitucional encontra-se sempre em conflito, pois a Constituição jurídica, no que tem de fundamental, ou seja, nas disposições que não dizem respeito à técnica, perece diariamente em face da Constituição real. Com isso, Lassalle estaria negando o Direito Constitucional e, por conseguinte, o próprio valor da Teoria Geral do Estado enquanto ciência. Contudo, essa teoria perde fundamento caso se possa admitir que a Constituição detém, de alguma forma, força própria, motivadora e ordenadora da vida do Estado.

Assim, a questão que emerge é sobre a força normativa da Constituição e, para se chegar a alguma conclusão, indagações devem ser feitas, como:

Existiria, ao lado do poder determinante das relações fáticas, expressas pelas forças políticas e sociais, também uma força determinante do Direito Constitucional? Qual o fundamento e o alcance dessa força do Direito Constitucional? Não seria essa força uma ficção necessária para o constitucionalista, que tenta criar a suposição de que o direito domina a vida 
do Estado, quando, na realidade, outras forças mostram-se determinantes? (HESSE, 1991, p. 11-12).

As respostas a essas perguntas servem de guia para a compreensão do conceito de Constituição jurídica e da própria definiçãa da ciência do Direito Constitucional, tratado como ciência normativa.

De acordo com o pensamento de Hesse, há três princípios que devem ser analisados ao tentar-se compreender a Constituição:

(...) o condicionamento recíproco existente entre a Constituição jurídica e a realidade político-social (1). Devem ser considerados, nesse contexto, os limites e as possibilidades da atuação da Constituição jurídica (2). Finalmente, hão de ser investigados os pressupostos de eficácia da Constituição (HESSE, 1991, p. 13).

O início do raciocínio para se chegar a uma resposta deve levar em consideração o condicionamento recíproco que existe entre a Constituição jurídica e a realidade político-social. Sendo assim, o significado da ordenação jurídica na realidade e em face desta só pode ser avaliado no caso de ambas, ordenação e realidade, serem consideradas no seu condicionamento recíproco, ou seja, no seu inseparável contexto. Caso seja realizada uma análise isolada, levando-se em consideração apenas um ou outro aspecto, não teremos as condições necessárias para se desenvolver uma resposta à questão. Como exposto por Hesse:

Para aquele que contempla apenas a ordenação jurídica, a norma 'está em vigor' ou 'está derrogada'; Não há outra possibilidade. Por outro lado, quem considera, exclusivamente, a realidade política e social ou não consegue perceber o problema na sua totalidade, ou será levado a ignorar, simplesmente, o significado da ordenação jurídica (HESSE, 1991, p. 13).

Essa análise é importante na percepção de que a norma constitucional não tem existência autônoma em face da realidade, ou seja, a sua vigência é a sua força motriz. Sendo assim, a situação regulada pela norma constitucional tem por pretensão ser concretizada no mundo real. Contudo, essa pretensão de 
eficácia da norma só ocorrerá realmente se as condições históricas daquele momento forem levadas em consideração. Assim, devem ser consideradas as condições naturais, técnicas, econômicas, e sociais.

Um segundo ponto a ser considerado para tentar responder tais questões é que devem ser examinados os limites e possibilidades de atuação do nosso ordenamento maior e, portanto, as Constituições real e jurídica encontram-se em uma relação de coordenação, não dependendo, todavia, pura e simplesmente, uma da outra. Explica Wilhelm Humboldt:

(...) somente a Constituição que se vincule a uma situação histórica concreta e suas condicionantes, dotada de uma ordenação jurídica orientada pelos parâmetros da razão, pode, efetivamente, desenvolver-se. (...) se as leis as leis culturais, sociais, políticas e econômicas imperantes forem ignoradas pela Constituição, careceria do imprescindível germe de sua força vital (HESSE, 1991, p. 16 e 18).

Um terceiro raciocínio para se chegar a uma conclusão tendo por base as questões suscitadas é por meio da análise dos pressupostos de eficácia da Constituição. O conteúdo da Constituição deve estar de acordo com as situações fáticas do presente, pois, dessa forma, melhor será desenvolvida a sua força normativa. Sendo assim, o nosso ordenamento maior deve incorporar parte da estrutura contrária se quiser manter a sua força normativa em um mundo em constante mudança, tanto política quanto social. Por conseguinte, a eficácia da Constituição, muitas vezes, só poderá ser assegurada através do controle de constitucionalidade.

A força normativa da Constituição se desenvolve da melhor forma quando congrega o seu conteúdo com a parcela do conhecimento voltada para as relações sociais e as reflexões políticas, econômicas e morais do seu tempo. Por isso, essa força é debilitada caso haja reformas constitucionais, pois isso reduz a confiança das pessoas na sua inquebrantabilidade. A estabilidade é pressuposto fundamental para a eficácia da Constituição. 
Além da estabilidade, a interpretação da Constituição também desenvolve papel de suma importância, visto que tem significado decisivo para a consolidação e preservação da força normativa da Constituição. Segundo Hesse,

A interpretação adequada é aquela que consegue concretizar, de forma excelente, o sentido da proposição normativa dentro das condições reais dominantes numa determinada situação. Em outras palavras, uma mudança das relações fáticas pode - ou deve - provocar mudanças na interpretação da Constituição (HESSE, 1991, p. 22-23).

Logo, é de se entender que a Constituição jurídica se encontra limitada pela realidade histórica do presente e a sua eficácia só pode ser realizada ao se levar em consideração essa realidade. Quando a força normativa da Constituição é posta em teste, nosso ordenamento maior não mais representa o presente, ou seja, nos encontramos em situações de emergência ou em tempos de necessidade.

Dessa forma, para Hesse, a Constituição jurídica não significa apenas um pedaço de papel, como considerado por Lassalle. O nosso ordenamento maior está atrelado à realidade histórica fática do presente. Contudo, não está condicionado apenas a essa realidade, contendo, mesmo que de forma limitada, uma força própria e ordenadora da vida do Estado.

O Direito Constitucional tem como meta a plena efetivação da força normativa da Constituição.

Em outros termos, o Direito Constitucional deve explicitar as condições sob as quais as normas constitucionais podem adquirir a maior eficácia possível propiciando, assim, o desenvolvimento da dogmática e da interpretação constitucional (HESSE, 1991, p. 27).

Por conseguinte, Hesse defende que o Direito Constitucional e a Constituição possuem certo grau de independência em relação à realidade político-social vigente. Sendo assim, esse Direito tem a capacidade de criar leis e normas gerais que tratem até mesmo das situações conflitantes, limitando-as. 
Além da força normativa do texto constitucional, é importante tratar-se do princípio da supremacia da Constituição, que é essencial para que a força desta seja efetiva. Com base nisso, as leis do nosso país têm que estar de acordo com as normas constitucionais, pois se não estiverem, serão, provavelmente, tidas como inválidas pelo controle de constitucionalidade. Contudo, não só as leis explícitas do texto constitucional devem ser respeitadas, como também os princípios constitucionais, tema do nosso capítulo seguinte. 


\section{Princípios constitucionais}

\subsection{Definição}

Exprimindo, com caráter de repertório jurídico, os valores eleitos como substanciais de dada ordem jurídica, os princípios constitucionais possuem conteúdo que se espraia sobre a integralidade do conjunto mandamental do direito, ou seja, expressos ou implícitos, são preceitos postos a plasmar a totalidade das regras jurídicas e submetê-las, todas, à axiologia da Lei Maior, de tal modo que se consolidam como verdadeiros vetores, diretrizes vinculantes da atividade legislativa infraconstitucional e de toda a estrutura juridicamente relevante subsequente.

Noção de princípio, segundo Celso Antônio Bandeira de Melo:

(...) é - por definição - mandamento nuclear de um sistema, verdadeiro alicerce dele, disposição fundamental que se irradia sobre diferentes normas compondo-lhes o espírito e servindo de critério para sua exata compreensão e inteligência exatamente por definir a lógica e a racionalidade do sistema normativo, no que lhe confere a tônica e lhe dá sentido harmônico (BANDEIRA DE MELLO, 2005, p. 903 apud ALMEIDA, 2011, p. 19).

Importante ressaltar que os princípios, que consagram valores ou determinam fins públicos a serem atingidos, impõem sua força vinculante aos diversos comportamentos sociais existentes, sendo eles públicos ou privados. Sendo assim, eles estão ligados aos três poderes da República, impondo limites e promovendo deveres sob a ótica legislativa e administrativa, e tratando do direcionamento do exercício de composição de interesses e de controle sob a perspectiva jurisdicional.

Segundo Luís Roberto Barroso (BARROSO, 2004), os princípios seriam bens sociais supremos, visto que não se esgotam na letra da lei, existindo eles tanto fora como acima desta. Isso é possível por eles não serem absolutos e se encontrarem em constante mutação. 
No que diz respeito à eficácia dos princípios não se pode esquecer que a norma deve ser observada, ou seja, deve haver uma obrigatoriedade de cumprimento. Sendo assim, aquele que deveria, mas não foi beneficiado pelos efeitos da norma, terá o direito de exigir, judicialmente, a produção dos referidos efeitos, assim como o emprego das condutas necessárias para que eles sejam realizados.

A capacidade normativa dos princípios pode assumir diversas modalidades de eficácia e algumas delas são especificadas por Luciana Dayoub:

(...) eficácia positiva ou simétrica, cujo objetivo é reconhecer direito subjetivo, àquele que deveria ser atingido pela realização dos efeitos da norma, de pleitear a tutela especifica da situação contemplada (diretamente ou por via judicial); eficácia vedativa de retrocesso, que, ligada primordialmente aos princípios relativos aos direitos fundamentais, e pressupondo que estes devem ser realizados por meio de regulamentação infraconstitucional, pretende a progressiva ampliação dos efeitos almejados e permite exigir-se, judicialmente, a invalidação de regulamentação revogadora de enunciados que ensejaram a aplicação e fruição dos referidos direitos; eficácia negativa, que autoriza sejam declaradas inválidas as normas ou atos que contrariem os efeitos pretendidos pela norma (ALMEIDA, 2011, p. 29).

Havendo conflito entre dois princípios, deve-se utilizar do mecanismo da ponderação, explicada de forma muito didática e coerente pela mesma autora:

(...) a ponderação, que resultará na decisão a respeito da aplicabilidade de uma ou outra norma, em função das circunstancias do caso concreto e conforme a dimensão axiológica relativa aos valores e fins que as normas procuram resguardar, caracteriza-se como o resultado de um juízo valorativo do aplicador, o qual, diante do caso examinado, atribui uma dimensão de peso a determinados elementos em detrimento de outros (...) (ALMEIDA, 2011, p. 31).

No entanto, esse mecanismo deve ser utilizado com certa restrição, visto que confere amplos poderes ao intérprete. Dessa forma, só deve ser usado nos 
casos em que for realmente exigido. Fora dessas situações, deverá ser motivada a razão de sua utilização.

\subsection{Princípios $\mathrm{x}$ regras}

Os princípios se distinguem das regras. Estas, segundo Ana Paula de Barcellos, são

(...) enunciados que estabelecem desde logo os efeitos que pretendem produzir no mundo dos fatos, efeitos determinados e específicos. Dependendo da complexidade do efeito pretendido, a regra pode demandar uma única conduta (muitas vezes descrita de forma direta no próprio enunciado), que não sofrerá alteração importante em decorrência dos diferentes ambientes de fato sobre os quais incidirá, ou condutas diversas, que variam em função dos fatos subjacentes, ainda que o efeito pretendido seja sempre o mesmo (BARCELLOS, 2011, p. 63).

Ana Paula de Barcellos (2011) trata de alguns dos critérios que têm sido apresentados para fazer essa diferenciação, sendo sete deles mais utilizados pela doutrina para esse fim. O primeiro critério diz respeito ao conteúdo, ou seja, à concepção segundo a qual os princípios estão mais relacionados às ideias de valor e direito, enquanto que as regras têm um conteúdo diversificado e não necessariamente moral. O segundo critério é o da validade, que se baseia na ideia de que a validade dos princípios advém do seu próprio conteúdo, ao passo que as regras derivam de outras regras ou princípios. O terceiro critério é o do compromisso histórico, que trata dos princípios serem tidos como universais, absolutos, objetivos e permanentes, sendo que as regras são caracterizadas pela relatividade de seus conteúdos, dependendo, assim, do tempo e lugar. O quarto critério é o da função no ordenamento, que trata dos princípios terem uma função explicadora e justificadora em relação às regras. O quinto critério é o da estrutura linguística, que explicita que os princípios são mais abstratos que as regras, visto que aqueles servem a um número indeterminado de situações, diferentemente destas. O sexto é o esforço interpretativo exigido, no qual os princípios exigem uma atividade 
argumentativa muito mais intensa para inferir a solução que eles propõem para o caso, enquanto as regras demandam apenas uma aplicabilidade. Por fim, o sétimo é a aplicação pelo qual as regras só podem ser válidas ou inválidas, ao passo que os princípios admitem uma aplicação mais ou menos ampla de acordo com as possibilidades fáticas e jurídicas existentes.

\subsection{Princípio da igualdade}

A igualdade formal encontra-se prevista na nossa Constituição Federal em seu artigo $5^{\text {o: }}$ "todos são iguais perante a lei sem distinção de qualquer natureza (...)”. Essa forma de igualdade também é reconhecida como isonomia, que é um dos princípios basilares do nosso ordenamento constitucional. A igualdade formal afirma que todos devem ser tratados de maneira igual, inexistindo qualquer tipo de diferença no tratamento entre os cidadãos. Essa forma de igualdade é tanto igualdade na lei, visto que observada pelos legisladores no momento de sua criação, quanto igualdade perante a lei, ou seja, observada no período da sua interpretação ou aplicação. Todavia, essa igualdade não é a ideal para certas situações, pois é limitada a uma igualdade independente de raça, orientação sexual ou qualquer outra forma de diversidade. Vivemos em um mundo bastante diversificado e, assim, a igualdade formal não considera os grupos desfavorecidos, que acabam sendo prejudicados.

No que diz respeito à igualdade material, esta é a busca pela igualdade real, ou seja, o dever tratar de forma desigual pessoas que se encontram em condições desiguais, na medida de suas desigualdades. Joaquim B. Barbosa Gomes explica muito bem o conceito ao dizer que

(...) em lugar da concepção 'estática' da igualdade extraída das revoluções francesa e americana, cuida-se nos dias atuais de se consolidar a noção de igualdade material ou substancial, que, longe de se apegar ao formalismo e à abstração da concepção igualitária do pensamento liberal oitocentista, recomenda, inversamente, uma noção 'dinâmica', 'militante' de igualdade, 
na qual necessariamente são devidamente pesadas e avaliadas as desigualdades concretas existentes na sociedade, de sorte que as situações desiguais sejam tratadas de maneira dessemelhante, evitando-se assim o aprofundamento e a perpetuação de desigualdades engendradas pela própria sociedade (GOMES, 2001, p. 130-131).

A igualdade material deve ser dirigida ao aplicador da norma, assim como ao legislador, pois este deve criar disposições iguais para tratar de situações idênticas e distintas para tratar de situações diferentes, na proporção exata da diversidade evidenciada. Isso, no entanto, não significa que o legislador possa discricionariamente fazer distinções tendo por base a norma jurídica, e sim possibilita que a legislação tutele as pessoas de forma desigual, levando em consideração os fatores de discriminação existentes no nosso texto constitucional.

Devido ao dever de tratamento igual ou desigual, Robert Alexy cria dois enunciados que esclarecem a aplicação do princípio da igualdade: "se não houver uma razão suficiente para a permissibilidade de um tratamento desigual, então, o tratamento igual é obrigatório", e "se houver uma razão suficiente para o dever de um tratamento desigual, então, o tratamento desigual é obrigatório" (ALEXY, 2008, p. 408-410 apud ALMEIDA, 2011, p. 50).

A igualdade material faz com que o Poder Público tenha que adotar medidas afirmativas com intuito de concretizar a igualdade, ou seja, distinguir, com base na lei, grupos de cidadãos que apresentam alguma vulnerabilidade que o sistema jurídico possa suprir por meio de políticas públicas. Assim, tais indivíduos serão elevados ao mesmo patamar dos demais, criando-se uma situação real de igualdade. Dessa forma, verifica-se a insuficiência de apenas se proibir a discriminação para se alcançar a efetividade da igualdade jurídica, pois, "de um conceito jurídico passivo mudou-se para um conceito jurídico ativo, quer-se dizer, de um conceito negativo de condutas discriminatórias vedadas passou-se a um conceito positivo de condutas promotoras da igualação jurídica" (ROCHA, 1996, p. 86-88 apud ALMEIDA, 2011, p. 51). 
Segundo Celso Antônio Bandeira de Mello, há três vetores que reconhecem e examinam as discriminações avaliando se houve ou não ofensa ao principio da igualdade:

(...) (a) o elemento tomado como fator de desigualação; (b) a correlação lógica abstrata existente entre o fator erigido em critério de discrímen e a disparidade estabelecida no tratamento jurídico diversificado; e (c) a consonância desta correlação lógica com os interesses absorvidos no sistema constitucional e destarte juridicizados (BANDEIRA DE MELLO, 2004, p.21-22 apud ALMEIDA, 2011, p. 52).

Quanto ao primeiro ponto, cabe destacar que a lei não pode se utilizar de elemento diferencial tão específico que acabe por singularizar um sujeito de modo absoluto no presente. Se isso ocorresse, estaria sendo violada a garantia individual, assim como estaria sendo reconhecido um favoritismo ao beneficiar apenas um indivíduo e, dessa forma, estaria sendo contrariado o duplo objetivo do princípio da igualdade. Assim, a norma deve se dirigir a sujeito indeterminado ou indeterminável no presente, havendo a possibilidade de abranger novos destinatários que não existiam na época da sua edição.

Em relação ao segundo vetor apresentado, deve existir uma justificativa racional para ocorrer o tratamento desigual. Não é admitida de forma alguma uma discriminação gratuita. Contudo, é característica do princípio da isonomia estabelecer tratamento específico a uma categoria de indivíduos quando houver adequação racional entre o elemento de discriminação e o regime especial dispensado.

No que diz respeito à discriminação com os interesses resguardados na Constituição, é de suma importância a compreensão de que a distinção de tratamento deve estar embasada em razão valiosa para o bem público, ou seja, a discriminação deve ter pertinência constitucional e se enquadrar nos padrões ético-sociais presentes deste ordenamento.

Luciana Dayoub resume bem o princípio da igualdade: 
Tem-se que o principio da igualdade, conforme atualmente delineado pela Carta da República, como resultado jurídico das aspirações da sociedade, possui como núcleo de sentido a existência de uma sociedade equalizada, ou seja, traz em si a ordem constitucional de que seja dispensado tratamento equânime aos indivíduos; a autorização para desequiparações pertinentes à aplicação de regimes jurídicos diferenciados, quando para tanto houver razões suficientes; e a determinação de corrigir-se, ou pelo menos mitigar, desigualdades fáticas de fundo econômico ou social, propiciando a efetiva realização da igualdade como fim público a ser perseguido (ALMEIDA, 2011, p. 57).

\subsection{Dignidade da pessoa humana}

O princípio da dignidade da pessoa humana encontra-se positivado no art. $1^{\circ}$, III, da Constituição Federal e é tido como um dos fundamentos da nossa República e em valor unificador dos direitos fundamentais. Fernando da Silva Mattos ensina:

Ao ser humano não se deve garantir apenas direitos relacionados à possibilidade de sobrevivência fática. A ideia de dignidade humana deve abarcar os mais diversos aspectos da vida e impõe, de um lado, o dever de abstenção de condutas que possam violá-la e, de outro, o dever de agir com o objetivo de alcançar sua efetividade e proteção (MATTOS, p. 3).

Este entendimento também é o de Ingo Wolfgang Sarlet:

(...) na condição de limite da atividade dos poderes públicos, a dignidade necessariamente é algo que pertence a cada um e que não pode ser perdido ou alienado, porquanto, deixando de existir, não haveria mais limite a ser respeitado (este sendo considerado o elemento fixo e imutável da dignidade). Como tarefa (prestação) imposta ao Estado, a dignidade da pessoa reclama que este guie as suas ações tanto no sentido de preservar a dignidade existente, quanto objetivando a promoção da dignidade, especialmente criando condições que possibilitem o pleno exercício e fruição da dignidade, sendo portanto dependente (a dignidade) da ordem comunitária, já que é de se perquirir até que ponto é possível ao indivíduo realizar, ele próprio, parcial ou totalmente, suas necessidades existenciais básicas ou se necessita, para tanto, do concurso do Estado ou da comunidade (...) (SARLET, p. 69).

São quatro os momentos considerados fundamentais para o desenvolvimento desse princípio: o Cristianismo, o Iluminismo, a obra de Immanuel Kant e o refluxo de horrores da Segunda Guerra Mundial. 
Em relação ao Cristianismo, foi a primeira vez que o ser humano passou a ser valorizado individualmente, já que a salvação anunciada não só era individual, como também dependia de uma decisão pessoal.

No que diz respeito ao movimento iluminista, com sua ideia basilar da razão humana, foi o responsável por retirar a religiosidade do centro do sistema de pensamento, substituindo-a pelo próprio homem. O desenvolvimento teórico do humanismo é um dos cernes para o desenvolvimento da ideia de dignidade humana, tendo por consequência a preocupação com os direitos individuais e o exercício democrático do poder.

Para Immanuel Kant, o homem é tido como um fim em si mesmo, não sendo, portanto, uma função do Estado, da sociedade ou da nação. O Direito e o Estado teriam o papel de estar organizados em benefício dos indivíduos. Dessa forma, Kant defende a necessidade da separação dos poderes e da generalização do princípio da legalidade, tendo por intuito assegurar aos homens a liberdade de perseguirem suas próprias vontades.

Já o sentimento de horror após a barbárie do nazismo e dos fascismos em geral levou, no pós-guerra, à consagração da dignidade da pessoa humana nos planos internacional e interno como valor supremo dos ordenamentos jurídicos e princípio orientador do agir estatal e dos organismos internacionais.

Mesmo com todo um processo histórico de desenvolvimento do princípio, a dignidade da pessoa humana é violada de diversas formas, mas uma delas deve aqui ser tratada em específico, que é a dos juristas que mantêm uma visão homofóbica ao reforçar e reproduzir os desejos da família patriarcal brasileira. Sendo assim, a heterossexualidade é tida como algo "normal" e a homossexualidade como algo "anormal", tratando-se os sujeitos que não estejam de acordo com esse dito parâmetro de "normalidade" estabelecido como indivíduos possuidores de menor dignidade. Ao reduzir a dignidade daqueles que não se enquadram nesse padrão de normalidade, tendo como base 
argumentos morais ou religiosos, nega-se a parte da população acesso pleno ao ideal de igualdade previsto na Constituição.

Esse direito à aplicação do princípio de forma igualitária é tratado por Fernando da Silva Mattos:

A sexualidade deve ser concebida como direito que decorre da própria condição humana, que tem como supedâneo a liberdade do individuo de se orientar sexualmente da maneira que quiser, sem ingerência por parte do Estado. $\mathrm{O}$ direito à igualdade não pode ser condicionado à orientação sexual do individuo (MATTOS, p. 5).

Dessa forma, é imprescindível que haja uma mudança de paradigma, no sentido de que os juristas não mais ouçam apenas os desejos da parcela heterossexual da população, como também sejam escutados os homossexuais, que almejam viver em uma sociedade na qual seus direitos sejam respeitados e garantidos. A população LGBT+ brasileira deve ter seus direitos assegurados com base no princípio explícito da dignidade da pessoa humana e no implícito do direito à busca da felicidade. Um dos instrumentos que possibilita essa equiparação de direitos, entre heterossexuais e homossexuais, são as ações afirmativas, que serão tratadas em um capítulo específico nessa monografia. 


\section{Direitos Fundamentais}

\subsection{História}

A história dos direitos fundamentais se inicia na Antiguidade grecoromana. Na sociedade desse período, somente os cidadãos da polis, ou, respectivamente, os cidadãos de Roma detinham direitos. Sendo assim, não havia a possibilidade de se almejar que todas as pessoas tivessem os mesmos direitos, pois isso geraria enormes repercussões na ordem estatal instaurada. No entanto, nesse âmbito histórico é possível encontrar considerações bastante relevantes para o desenvolvimento da ideia dos direitos fundamentais.

Nesse sentido, podemos tratar dos ideais de Platão e Aristóteles, visto que aquele tinha como obrigatórias apenas as leis que derivassem da razão, enquanto este acreditava que a proteção da vida e da propriedade dos cidadãos era dever do Estado e versava sobre a justiça como uma virtude que deveria preservar a igualdade perante outros. Com base nesse panorama é possível perceber que na antiguidade greco-romana já se formulavam ideias sobre direitos humanos, mas faltava a transformação destas em direito vigente.

Após esse período, ocorre o momento histórico conhecido como Idade Média, no qual o Cristianismo contribuiu fortemente para o desenvolvimento dos direitos fundamentais. Importante ressaltar nessa fase o ensinamento do homem como imagem e semelhança de Deus, o que possibilitou a formação do pensamento da dignidade da pessoa humana e a ideia de liberdade pessoal. Além disso, importante lembrar também dos ideais defendidos por Tomás de Aquino, entre eles, em especial, o de que a autoridade que intervém na vida, na pessoa ou na propriedade dos seus súditos é vista como injusta, visto que aqueles direitos são resguardados por Deus.

Nesse período foi realizada uma das mais famosas declarações de direitos, conhecida como Magna Carta do ano de 1215. Esse documento constitui uma convenção feita entre o monarca e os barões feudais da Idade 
Média, na qual lhes eram reconhecidos certos privilégios. A partir da Magna Carta a soberania do rei passava a ser consideravelmente limitada por prerrogativas estamentais, que beneficiavam todos os membros das ordens privilegiadas da época, como nobreza e clero. Ainda mais importante do que essa redução da soberania é que com essa declaração há uma percepção implícita de que o rei se encontrava vinculado pelas próprias leis que criava. Ademais, os direitos da nobreza e do clero existiam sem haver necessidade de passar pelo crivo do monarca e eles também não podiam ser modificados por vontade deste. Sendo assim, pela primeira vez na história havia a limitação do poder do rei por meio de um direito objetivo. Todavia, direitos subjetivos e liberdades para todo indivíduo ainda não estavam garantidos, visto que os direitos garantidos estavam ligados à propriedade dos feudos e não à cidadania como ocorre em uma Constituição.

Com as grandes navegações e a tomada de Constantinopla se inicia a Idade Moderna, período no qual ocorre uma mudança na relação entre a liberdade e a obrigação para com o Estado em detrimento dos privilégios recém-conquistados pelas castas. Contudo, há uma distinção nas divergências entre as castas e o monarca na Europa continental e entre este e o parlamento na Inglaterra. Isso porque o parlamento inglês representava a coletividade e, assim, enquanto aumentava o número de movimentos contra o absolutismo monárquico na Europa continental, inexistiam esses movimentos contrários ao absolutismo parlamentarista inglês, pois este absolutismo tinha por intuito a manutenção dos direitos já conquistados e a conquista de outros direitos.

O período conhecido como Idade Moderna caracterizou-se pelo pensamento de diversos pensadores que foram muito importantes no desenvolvimento dos direitos humanos como os conhecemos hoje. Dentre eles, devemos tratar, no momento histórico da Reforma Protestante, de Martinho Lutero, que afirmava a possibilidade das pessoas contrariarem a autoridade mandamental em questões de viés religioso e de João Calvino, que defendia a 
obrigação por parte da autoridade de promover o bem-estar da população, assim como de respeitar os direitos fundamentais.

Dentro da contribuição inglesa para a formação dos direitos fundamentais, podemos falar sobre Thomas Hobbes, que defendia a existência de um contrato social no qual as pessoas se obrigariam a obedecer a uma autoridade e renunciariam aos seus direitos naturais. Assim, todos os cidadãos se submeteriam à autoridade máxima, que seria a única fonte para o direito. Já o Estado teria a responsabilidade de manter a paz e a ordem. Em contraponto a Hobbes há o pensamento de John Locke, que tratava da existência dos direitos naturais, mas também de direitos individuais e irrenunciáveis que estariam acima dos direitos naturais no estado natural. Além disso, Locke tratava da possibilidade de destituir o governante caso este não cumprisse as obrigações estipuladas no contrato social.

Em relação à contribuição francesa, importante tratar das teorias de Montesquieu e Rousseau. Para o primeiro, é essencial a garantia da liberdade do cidadão e o bem-estar do povo. Quanto a Rousseau, defendia a formulação de um contrato social no qual haveria a total submissão dos interesses particulares em prol da vontade geral.

Já em relação à contribuição alemã é imprescindível que se fale de Immanuel Kant, que estudou a diferença entre direitos naturais inatos e os direitos adquiridos. $\mathrm{O}$ direito inato não teria o condão de ser restringido além do que fosse suficiente para garantir a liberdade de todos.

No período histórico moderno, além dos pensadores é importante ressaltar também as primeiras declarações nacionais de direitos consideradas relevantes e que possibilitaram o desenvolvimento dos direitos fundamentais. Cabe, primeiramente, tratar das duas declarações firmadas na Inglaterra: o Habeas Corpus $\mathrm{Act}^{1}$, que diz respeito a uma garantia judicial voltada a proteger a liberdade de locomoção, o qual se tornou a base para a proteção de outras

\footnotetext{
${ }^{1}$ Habeas Corpus Act, London 1679.
} 
liberdades fundamentais; e o Bill of Rights ${ }^{2}$, que criava uma garantia institucional, ou seja, uma forma de organização do Estado cuja função, em última análise, é proteger os direitos fundamentais.

Em relação aos Estados Unidos da América, ressalta-se a Virginia Bill os Rights ${ }^{3}$, que reconhecia em seu art. $1^{\circ}$ que todos os homens eram, por natureza, igualmente livres e independentes e possuíam certos direitos inatos, dos quais não poderiam ser privados por qualquer tipo de acordo. Sendo assim, pela primeira vez na história os direitos fundamentais advindos dessa declaração não estavam à disposição dos representantes do povo, caracterizando direitos supra estatais, ou seja, direitos inalienáveis e irrevogáveis. Enquanto as declarações inglesas tratavam primordialmente de direitos relativos aos seus próprios cidadãos, a Virginia Bill of Rights reconhecia direitos naturais e inatos a todo e qualquer indivíduo. Essa declaração teve a sua continuação na Declaração Americana de Independência de 1776.

A Declaração de Independência de 1776 é importante por ter sido o primeiro documento a afirmar os princípios democráticos na história política moderna. Sendo assim, reconhece a existência de direitos inerentes a todo ser humano, independentemente de sexo, raça, religião, cultura ou posição social. Como bem tratado por Fábio Konder Comparato:

(...) a ideia de uma declaração à humanidade está intimamente ligada ao princípio da nova legitimidade política: a soberania popular. Uma nação só está legitimada a auto afirmar sua independência, porque o povo que a constitui detém o poder político supremo. (COMPARATO, 2003, p. 63)

\footnotetext{
${ }^{2}$ Bill Of Rights, London 1689.

${ }^{3}$ Virginia Bill of Rights. Virginia, 1776.
} 
Por meio dessa Declaração, os norte-americanos transformaram os direitos naturais em direitos positivos, dando aos direitos humanos a qualidade de direitos fundamentais, elevando-os ao nível constitucional.

Dentro do território francês, é importante tratar da Declaração dos Direitos do Homem e do Cidadão $^{4}$, que possui uma forte influência constitucional americana e de ideias e teorias dos filósofos franceses, como Montesquieu e Rousseau. Essa declaração deixou evidente que a postulação de direitos naturais, inatos, supra estatais e inalienáveis era a condição necessária para dar um fim aos abusos despóticos. Além desse documento, tem-se, ainda, a declaração de direitos na Constituição Francesa de 1791, na qual foi reconhecida, pela primeira vez na história, a existência de direitos humanos de caráter social. Ademais, na Constituição Francesa de 1848 há duas disposições que merecem destaque, segundo Comparato:

Pela primeira vez, na história Constitucional, a pena de morte é abolida em matéria política (art. 5) ${ }^{5}$. Por outro lado, repristinando o Decreto da Convenção de 1793, revogado pelo consulado em 1802, proibiu-se a escravidão em "todas as terras francesas" (art. 6) ${ }^{6}$ (COMPARATO, 2003, p. 102).

Com a Queda da Bastilha, em 1789, dá-se início à Idade Contemporânea, que perdura até os dias atuais. Nesse período ocorreu a Convenção de Genebra $^{7}$, que foi muito importante por tratar pela primeira vez do que hoje chamamos de direito humanitário em matéria internacional. Esse direito é composto por leis e costumes da guerra com intuito de reduzir o sofrimento dos soldados feridos e doentes, assim como de populações de civis atingidas por algum conflito bélico. Sendo assim, é a primeira introdução dos direitos humanos na esfera internacional.

\footnotetext{
${ }^{4}$ Declaração dos Direitos do Homem e do Cidadão, Paris 1789.

${ }_{6}^{5}$ Artigo V: Ninguém será submetido à tortura, nem a tratamento ou castigo.

${ }^{6}$ Artigo VI: Todo homem tem direito de ser, em todos os lugares, reconhecido como pessoa perante a lei.

${ }^{7}$ Convenção de Genebra, Genebra 1864.
} 
Foi promulgada também nessa fase a Constituição Mexicana de 1917, a primeira carta política que tratou dos direitos trabalhistas como direitos fundamentais, de forma conjunta com as liberdades individuais e os direitos políticos. Contudo, é importante ressaltar que nem todos os direitos trabalhistas declarados na Constituição podem ser considerados, objetivamente, como direitos humanos. Essa carta estabeleceu o princípio da igualdade substancial de posição jurídica entre trabalhadores e empresários na relação contratual de trabalho.

Além da Constituição Mexicana, também temos a Constituição Alemã, em 1919, que defendia o fim das desigualdades devido ao princípio da isonomia e a proteção e o respeito às diferenças. Assim como na Constituição Mexicana, os direitos trabalhistas e previdenciários foram elevados ao nível constitucional de direitos fundamentais.

De suma importância é a Declaração Universal dos Direitos Humanos de 1948, que ao retomar os ideais da Revolução Francesa representou o reconhecimento dos valores supremos da igualdade, da liberdade e da fraternidade entre os homens, como exposto em seu artigo $1^{8}$. Além disso, essa Declaração levou ao reconhecimento da igualdade essencial de todo ser humano em sua dignidade de pessoa, ou seja, como fonte de todos os valores, independentemente das distinções de raça, cor, religião ou qualquer outra condição, como disposto no artigo II, inciso $1^{9}$.

Outra convenção que deve ser lembrada é a Convenção Americana de Direitos Humanos de 1969, que tornou possível a aplicação do princípio da prevalência dos direitos mais vantajosos para a pessoa humana. Isso significa que na vigência simultânea de vários sistemas normativos ou na de vários

\footnotetext{
${ }^{8}$ Artigo I: Todos os seres humanos nascem livres e iguais em dignidade e direitos. São dotados de razão e consciência e devem agir em relação uns aos outros com espírito de fraternidade.

${ }^{9}$ Artigo II: 1 - Todo ser humano tem capacidade para gozar os direitos e as liberdades estabelecidos nesta Declaração, sem distinção de qualquer espécie, seja de raça, cor, sexo, idioma, religião, opinião política ou de outra natureza, origem nacional ou social, riqueza, nascimento, ou qualquer outra condição.
} 
tratados internacionais, em matéria de direitos humanos, deve ser aplicado aquele que melhor protege o indivíduo.

Além dessas convenções, encontramos a Carta Africana dos Direitos Humanos e dos Direitos dos Povos ${ }^{10}$, na qual se afirmou que os povos também são titulares de direitos humanos, tanto no plano interno quanto na esfera internacional. Esse ideal encontra-se disposto no art.XIX ${ }^{11}$ da Carta.

Por fim, cabe citar o Estatuto do Tribunal Penal Internacional de 1988. Trata-se da instituição de um regime de verídica cidadania mundial. Sendo assim, todas as pessoas, naturais ou jurídicas, de qualquer nacionalidade, têm direitos e deveres com a humanidade. Dessa forma, considera a fixação de regras de responsabilidade penal em escala planetária, tendo por intuito a sanção da prática de atos que prejudiquem a dignidade humana.

\subsection{Eficácia}

As normas de direitos fundamentais não são homogêneas no que diz respeito à função que exercem na Constituição e às técnicas de positivação utilizadas. Segundo Ingo Sarlet:

A carga eficacial será diversa em se tratando de norma de natureza programática (ou - se preferirmos - de cunho impositivo), ou em se tratando de forma de positivação que permita, desde logo, o reconhecimento de direito subjetivo ao particular titular do direito fundamental (SARLET, 2012, p. 235).

Além disso, há as diferentes funções dos direitos fundamentais, que os dividem em dois grupos: os direitos de defesa, como liberdade e igualdade; e os direitos a prestações, como o direito à proteção. Os direitos de defesa, por serem relativos a uma abstenção por parte do Estado, são possíveis de serem aplicados de forma imediata, enquanto os direitos a prestações, por exigirem

\footnotetext{
${ }^{10}$ Carta Africana dos Direitos Humanos e dos Direitos dos Povos, Nairóbi 1981.

${ }^{11}$ Artigo XIX: Todos os povos são iguais; eles devem gozar do mesmo respeito e ter os mesmos direitos. Nada justifica a dominação de um povo sobre outro.
} 
um comportamento ativo dos destinatários, fazem com que boa parte da doutrina lhes negue aplicabilidade imediata e, por conseguinte, plena eficácia.

Ingo Sarlet ensina que, no nosso país, todas as normas de direitos fundamentais encontram-se sujeitas ao mesmo regime jurídico. Todavia, isso não quer dizer que todas essas normas tenham aplicabilidade direta, pois, em alguns casos, é necessária a interposição do legislador para que gerem efeitos. Como bem exposto pelo autor, "O fato de todas as normas de direitos e garantias fundamentais terem reconhecida sua direta aplicabilidade, não corresponde a afirmar que a eficácia jurídica (que não se confunde com a eficácia social ou efetividade) de tais normas seja idêntica" (SARLET, 2012, p. 314). Sendo assim, a questão da aplicação direta dos direitos fundamentais está relacionada a todos eles independentemente da sua função ou técnica de positivação. Nesse âmbito, a aplicação imediata desses direitos vai depender da sua categoria, ou seja, se são de defesa ou prestacionais.

Em relação aos direitos de defesa, estes independem de um agir do Estado ou de particulares, e sim de uma abstenção por parte destes. Por isso, eles possuem a possibilidade de gerar de forma imediata os seus efeitos, sem necessidade do legislador ordinário, sendo, portanto, de aplicação prática.

Já no que concerne aos direitos prestacionais, estes são distintos dos direitos de defesa, visto que pressupõem uma conduta positiva do Estado ou de particulares. Além disso, essa categoria de direitos fundamentais tem o custo como elemento relevante, conforme acentuado por parcela significativa da doutrina, ou seja, a efetiva realização das prestações reclamadas não é possível sem que se despenda algum recurso. Com base nisso, é de fácil percepção a problemática da disponibilidade do objeto pelo seu destinatário, pois este tem que deter os recursos necessários para que possa prestar de forma efetiva os direitos garantidos na Constituição. A capacidade de disposição sobre os direitos por parte do Estado é limitada, o que é um obstáculo para a sua eficácia. Ademais, o Estado deve ter a capacidade jurídica de implementar os 
direitos em questão. Contudo, os direitos prestacionais não podem depender integralmente da figura do legislador ordinário para que tenham sua eficácia e efetividade garantidas, pois a decisão em relação ao conteúdo desses direitos não pode ser realizada de forma plena e ilimitada pelo legislador.

Além das diferenças existentes entre a eficácia das normas de direitos fundamentais negativos e prestacionais, há também as características comuns à eficácia de qualquer categoria de direito fundamental, como exposto por Ingo Sarlet:

1) revogam todos os atos normativos anteriores e contrários à norma definidora de direito fundamental; 2) estabelece limites ao legislador, que não poderá afastar-se dos parâmetros estabelecidos nas normas de direitos fundamentais no exercício de sua função; 3) impõe a declaração de inconstitucionalidade de leis e atos normativos editados após a vigência da CRFB/1988; 4) constituem parâmetro de interpretação, integração e aplicação das normas constitucionais e infraconstitucionais; 5) impõem ao Estado que se abstenha de atuar contrariamente à norma definidora de direito fundamental; 6) impedem o legislador de abolir direitos fundamentais já outorgados (vedação ao retrocesso). (SARLET, 2012, p. 261-263).

Os direitos fundamentais, ainda segundo Sarlet, possuem uma eficácia irradiante, o que significa que os valores abarcados por esses direitos positivados se propagam por todo o ordenamento jurídico e, assim, devem ser seguidos ao se interpretar os dispositivos infraconstitucionais e na atuação executiva, legislativa e judiciária.

No que cabe à destinação, não há nada expresso na Constituição, mas podemos inferir que seja aos órgãos estatais, sendo conhecida como eficácia vertical dos direitos fundamentais. Entretanto, esses direitos também podem ser atingidos por ações de um particular contra outro no que é conhecido como eficácia horizontal dos direitos fundamentais, ou seja, a necessidade de que eles sejam respeitados e protegidos nas relações privadas além da relação entre Estado e particular. A questão dos particulares também serem destinatários das normas de direitos fundamentais não é mais um ponto de divergência na 
doutrina brasileira. Contudo, o que gera controvérsias é o modo pelo qual se vinculam os particulares e os efeitos decorrentes dessa vinculação. A partir disso, os doutrinadores divergem: aqueles que defendem a eficácia indireta dessas normas nas relações entre particulares, havendo a necessidade de uma ação por parte do legislador para que possam ser implementadas; e aqueles que tratam da eficácia direta e que, a partir disso, entendem que a vinculação dos particulares aos direitos fundamentais gera efeito desde logo. A jurisprudência nos tribunais superiores brasileiros tem indicado que há a prevalência da tese da eficácia direta dos direitos fundamentais na esfera das relações entre particulares. 


\section{Movimento LGBT+e demandas conquistadas}

O movimento LGBT+ deve ser compreendido de duas formas. A primeira é como uma ação coletiva que tem por intuito a defesa e promoção dos interesses dos grupos que o compõem. Deve ser entendido também como um "movimento guarda-chuva", pois reúne diversas pessoas e suas experiências de vida, sendo que cada uma daquelas possui suas demandas específicas. Dessa forma, esse movimento abarca inúmeras vontades que podem atender a alguns indivíduos ou a todos os componentes da causa.

Em perspectiva global, a necessidade do surgimento de um movimento LGBT+ estruturado ocorre na segunda metade do século $\mathrm{XX}$, estando associado à Revolta de Stonewall, na qual frequentadores do bar gay Stonewall, em Nova York, resistiram e enfrentaram as forças policiais que fizeram uma batida no estabelecimento. Essa revolta ocorreu na madrugada do dia 28 de junho de 1969. A partir deste episódio é que o movimento se organiza nos Estados Unidos e incita a luta por direitos ao redor do globo. $\mathrm{O}$ que se exige são transformações profundas/reais no tratamento da homossexualidade tanto pelo Estado quanto pelo Direito.

Manuel Castells trata do surgimento do movimento LGBT+ atrelado a três fatores, sendo eles: "um espírito de intensa agitação social e rebelião que marcou a década de 1960; a repressão violenta aos homossexuais que acabou provocando radicalização; e o impacto do feminismo sobre o patriarcalismo". (CASTELLS, 1999, p. 240 apud CARDINALI, 2018, p. 12). O patriarcalismo se encontra em risco pelo avanço do movimento LGBT+ por este confrontar a ideia de que a heterossexualidade é compulsória, colocando em perigo a divisão de papéis tanto de gênero quanto sexuais. A partir disso, Castells entende que:

Os movimentos lesbiano e gay são simples movimentos em defesa do direito humano básico de escolher a quem e como amar. São também expressões 
poderosas de identidade sexual e, portanto, de liberação sexual. Esses movimentos desafiam algumas das estruturas milenares sobre as quais as sociedades foram historicamente construídas: repressão sexual e heterossexualidade compulsória (CASTELLS, 1999, p. 256 apud CARDINALLI, 2018, p. 13).

O movimento LGBT+ é considerado um dos novos movimentos sociais emergidos na segunda metade do século XX. Isso porque esse movimento foge do paradigma daquele momento, visto que o que se busca são transformações culturais e simbólicas, enquanto o foco, na época, era a luta do proletariado por bens materiais. Devido a isso, este movimento é visto como um movimento de demanda de reconhecimento, pois tem por intuito a luta em torno de políticas identitárias. Nancy Fraser trata muito bem dessas políticas de reconhecimento sob o viés LGBT ao dizer que:

(...) a desigualdade/ injustiça sob a ótica do reconhecimento é encarada por um viés primordialmente cultural, como uma questão de status. Assim, devese analisar os padrões institucionalizados de valor cultural pelos seus efeitos sobre a posição relativa dos atores sociais; isto é, quando estes padrões encararem os atores como iguais, conferindo-os o mesmo valor, poderia se falar em igualdade e reconhecimento recíproco, ao passo que padrões hierarquizantes, que encaram os atores como inferiores ou superiores, produziriam exclusão e desigualdade, por meio de uma subordinação de status e não reconhecimento (FRASER, 2004, p. 29-30 apud CARDINALI, 2018, p. 14).

O movimento LGBT+ tem a importante tarefa de ressignificar as identidades recriminadas pelos diversos discursos, como religioso, jurídico e médico, construindo o seu próprio sentido. Dessa forma, ser LGBT não será mais um motivo de vergonha, e sim de neutralidade, sendo o homossexual tratado como igual em relação aos heterossexuais, ou, até mesmo, de orgulho.

\subsection{Movimento LGBT+ brasileiro}

Neste trabalho, a formação histórica do movimento LGBT brasileiro vai ser analisada tendo como ponto de partida a teoria de Regina Facchini. 
Segundo ela, a história do movimento pode ser dividida em três ondas sucessivas, sendo elas:

(...) $1^{\mathrm{a}}$ onda, surgimento do movimento no final da ditadura militar em um cenário marcado pela desconfiança em relação ao Estado e pela contracultura; $2^{\mathrm{a}}$ onda, caracterizada pelo arrefecimento do movimento incipiente em função da epidemia de AIDS e a luta pelo reconhecimento da diversidade sexual na Constituinte; e $3^{\mathrm{a}}$ onda, em que o movimento se institucionaliza e profissionaliza, construindo alianças com o Estado e formulando um discurso reivindicatório marcado pelo pragmatismo e pela linguagem dos direitos (FACCHINI, 2005 apud CARDINALI, 2018, p. 15).

O início do movimento no Brasil, ou seja, a primeira onda, ocorre a partir do final da década de 1970, em um momento no qual o país se encontrava sob a ditadura civil-militar, bastante marcado pela contracultura e pela eclosão dos novos movimentos sociais, como já mencionado. Mesmo com o ideal de abertura lenta e gradual proposto pelo regime, os militares não permitiam qualquer discussão a respeito de sexualidade. Nesse período, o discurso em voga era o de defesa de certo modelo de família cristã, o que impossibilitava qualquer abertura para o movimento LGBT+ trazer suas demandas para serem avaliadas e acatadas. No entanto, havia o fortalecimento da contracultura, que resistia a todos os valores defendidos pela ditadura, rompendo com os padrões de moralidade e noções de gênero tradicionais. Alguns artistas, como Caetano Veloso e Ney Matogrosso, foram deveras importantes no rompimento com o conservadorismo do período ao aderirem a um perfil andrógino e por trazerem o questionamento em relação às representações de masculino e feminino.

Em relação à segunda onda, esta tem início na década de 1980, quando as primeiras vítimas da AIDS são descobertas no país. Em um primeiro momento, o movimento se cindiu, havendo aqueles que, por adotarem um discurso liberal no que diz respeito à sexualidade, acreditavam que a doença era uma forma de reduzir o contato sexual na comunidade LGBT+e, por isso, relutavam em adotar as medidas cabíveis para o enfrentamento da doença. Esses que eram 
contra o enfrentamento também argumentavam que ao se dar tanto enfoque à AIDS, talvez se reforçasse a ideia de que a homossexualidade estava atrelada à doença.

Havia, todavia, a parcela do movimento que de início percebeu a urgência em se levar a doença a sério e, assim, desde a sua descoberta no país, já desenvolvia um trabalho assistencialista emergencial e recorria ao governo para ajuda no combate à moléstia. Essa atitude foi positiva, pois por meio dela houve uma resposta estatal estruturada ainda nos primeiros anos da epidemia.

A doença atingiu indivíduos considerados socialmente estigmatizados, o que acarretou discursos de culpabilização da vítima, sob a ótica científica, e de castigo divino, pelo lado religioso. Dessa forma, a epidemia de AIDS acabou por reforçar o discurso conservador protegido nesse período a respeito da defesa da família tradicional e monogâmica. Entretanto, a enfermidade em questão também teve efeitos positivos para a comunidade LGBT+, visto que as práticas sexuais homossexuais tornaram-se centro das discussões, sendo que anteriormente à doença elas ficavam no âmbito da clandestinidade. Por conta disso, o Estado passou a se preocupar mais com as questões relacionadas à comunidade e mudou diametralmente de posição, deixando de ser um inimigo para se tornar um aliado da causa.

No período da segunda onda, mesmo sendo um momento de desmobilização da comunidade, houve grandes conquistas para a causa, tais como: a retirada da homossexualidade do código de doenças do Instituto Nacional de Assistência Médica da Previdência Social, assim como a adoção e disseminação da ideia de orientação sexual, em substituição à ideia, errônea, de opção sexual.

A terceira onda tem seu começo em 1990 com o aumento dos grupos presentes na comunidade, maior periodicidade de encontros nacionais, aumento das demandas e a fundação dos primeiros grupos defensores especificamente dos direitos de transexuais e travestis. A aliança entre a 
comunidade LGBT+ mostrou-se profissionalizada e institucionalizada, e o Estado se tornou ainda mais forte nesse período. Essa aliança é nítida em diversos âmbitos, como expresso por Daniel Cardinali:

A aliança do movimento com o Estado se reflete, ainda, em outros âmbitos. Assim, por exemplo, diversos partidos políticos criaram setoriais LGBT a partir da década de 1990, lançando candidatos aliados da causa e formulando projetos de lei e políticas públicas em atendimento às demandas do movimento (CARDINALI, 2018, p. 26).

Além disso, é a partir dessa época que o movimento multiplica as identidades dos seus sujeitos políticos, ou seja, inclui, de forma progressiva, as demandas das siglas mais estigmatizadas da comunidade, como as travestis e transexuais, o que acaba por aumentar a quantidade de siglas denominativas dos grupos que compõem o movimento.

O movimento LGBT+ começa a se relacionar com o mercado ao ocorrer a promoção, cada vez maior, de serviços e estabelecimentos destinados ao público gay, que, nesse contexto, é chamado de público GLS (gays, lésbicas e simpatizantes). Em 1990, o direito do consumidor passa a tomar força e, com isso, há uma disseminação maior por medidas antidiscriminatórias nos estabelecimentos. Isso deu abertura para que fossem aprovadas leis contra a homofobia em estabelecimentos comerciais por vários Estados e Municípios, assim como a iniciativa mais conhecida desse período em questão, que são as Paradas do Orgulho LGBT.

Daniel Cardinali trata da possibilidade de uma quarta onda, que segundo alguns autores seria

(...) advinda da ascensão do PT ao poder em 2003, pois com isso os militantes do movimento LGBT teriam se deslocado para dentro da própria estrutura do Estado, o que teria se refletido no incremento e multiplicação de políticas públicas e ações governamentais voltadas a esta população, gerando uma nova relação apta a caracterizar uma "quarta onda" (CARDINALI, 2018, p. 30). 
O movimento LGBT+ continua galgando espaço no cenário mundial e brasileiro e, dessa forma, há o reconhecimento de novas identidades, como a assexualidade. Há também a melhor organização de grupos considerados excluídos dentro do movimento, como lésbicas, bissexuais e travestis. Ocorre ainda a formação de grupos que têm o ponto de vista da interseccionalidade, fazendo com que pessoas LGBT negras ou deficientes sejam integradas à causa.

Com o passar do tempo, o movimento LGBT+ conseguiu centralizar suas demandas em conquistas mais prováveis ao invés de não seguir uma pauta organizada de reivindicações. Por conta disso, a causa precisou formular as suas demandas tendo por base argumentos constitucionais, o que torna possível que suas reivindicações sejam aceitas pelo Poder Legislativo. Dessa forma, esse movimento persiste no reconhecimento de diversos direitos, tendo sido alguns deles reconhecidos, como a união estável e o casamento homoafetivo, assim como a criminalização da homofobia. Todavia, ainda faltam muitos direitos a serem reconhecidos, principalmente às minorias estigmatizadas do movimento, como as causas transexuais e travestis.

\subsection{União homoafetiva}

O nosso texto constitucional não trata de forma explícita dos relacionamentos na seara homoafetiva, assim como da orientação sexual das pessoas. Essa lacuna constitucional poderia ter sido coberta pelo Código Civil de 2002. Contudo, este se manteve silente em relação a ambas as questões.

O instituto da união estável encontra-se regulamentado no $\S 3^{\circ}$ do art. 226 da nossa Carta Magna, que diz: "Para efeito da proteção do Estado, é reconhecida a união estável entre o homem e a mulher como entidade familiar, devendo a lei facilitar sua conversão em casamento". Com base nisso, grande parte das pessoas defende que a interpretação desse parágrafo deve se dar de maneira restritiva, abarcando apenas o relacionamento entre um homem e uma 
mulher e, sendo assim, defendem ferrenhamente a impossibilidade de uma interpretação que abranja um casal homossexual.

No entanto, em 2011, o STF, em uma tentativa de amenizar os efeitos causados pela omissão do legislador e reparar as divergências até então existentes, reconheceu a legitimidade constitucional das uniões homoafetivas no julgamento conjunto da ADI 4277 e da APDF 132. O intuito de ambas as ações era o de que fosse dada interpretação conforme a Constituição ao art.1723 do Código Civil, que regula as uniões estáveis, para entender-se que no mesmo dispositivo estariam abrangidas as uniões homoafetivas. A decisão foi unânime a favor da garantia desse direito à população LGBT+ e constituiu uma das grandes vitórias do movimento até hoje no nosso país, como pode ser visto na ementa da $\mathrm{ADI} 4277$ :

Ementa: 1. Arguição de Descumprimento de Preceito Fundamental (ADPF). Perda parcial de objeto. Recebimento, na parte remanescente, como Ação Direta de Inconstitucionalidade. União homoafetiva e seu reconhecimento como instituto jurídico. Convergência de objetos entre ações de natureza abstrata. Julgamento conjunto. Encampação dos fundamentos da ADPF no $132-R J$ pela ADI n ${ }^{\circ}$ 4.277-DF, com a finalidade de conferir "interpretação conforme à Constituição" ao art. 1.723 do Código Civil. Atendimento das condições da ação. 2. Proibição de discriminação das pessoas em razão do sexo, seja no plano da dicotomia homem/mulher (gênero), seja no plano da orientação sexual de cada qual deles. A proibição do preconceito como capítulo do constitucionalismo fraternal. Homenagem ao pluralismo como valor sócio-político-cultural. Liberdade para dispor da própria sexualidade, inserida na categoria dos direitos fundamentais do indivíduo, expressão que é da autonomia de vontade. Direito à intimidade e à vida privada. Cláusula pétrea. O sexo das pessoas, salvo disposição constitucional expressa ou implícita em sentido contrário, não se presta como fator de desigualação jurídica. Proibição de preconceito, à luz do inciso IV do art. $3^{\circ}$ da Constituição Federal, por colidir frontalmente com o objetivo constitucional de "promover o bem de todos". Silêncio normativo da Carta Magna a respeito do concreto uso do sexo dos indivíduos como saque da kelseniana "norma geral negativa", segundo a qual "o que não estiver juridicamente proibido, ou obrigado, está juridicamente permitido". Reconhecimento do direito à preferência sexual como direta emanação do princípio da "dignidade da pessoa humana": direito a auto-estima no mais elevado ponto da consciência do indivíduo. Direito à busca da felicidade. Salto normativo da proibição do preconceito para a proclamação do direito à liberdade sexual. $\mathrm{O}$ concreto uso da sexualidade faz parte da autonomia da vontade das pessoas naturais. Empírico uso da sexualidade nos planos da intimidade e da privacidade constitucionalmente tuteladas. Autonomia da vontade. Cláusula pétrea. 3. Tratamento constitucional da instituição da família. Reconhecimento de que a Constituição Federal não empresta ao substantivo "família" nenhum 
significado ortodoxo ou da própria técnica jurídica. A família como categoria sóciocultural e princípio espiritual. Direito subjetivo de constituir família. Interpretação não-reducionista. O caput do art. 226 confere à família, base da sociedade, especial proteção do Estado. Ênfase constitucional à instituição da família. Família em seu coloquial ou proverbial significado de núcleo doméstico, pouco importando se formal ou informalmente constituída, ou se integrada por casais heteroafetivos ou por pares homoafetivos. A Constituição de 1988, ao utilizar-se da expressão "família", não limita sua formação a casais heteroafetivos nem a formalidade cartorária, celebração civil ou liturgia religiosa. Família como instituição privada que, voluntariamente constituída entre pessoas adultas, mantém com o Estado e a sociedade civil uma necessária relação tricotômica. Núcleo familiar que é o principal locus institucional de concreção dos direitos fundamentais que a própria Constituição designa por "intimidade e vida privada" (inciso X do art. $5^{\circ}$ ). Isonomia entre casais heteroafetivos e pares homoafetivos que somente ganha plenitude de sentido se desembocar no igual direito subjetivo à formação de uma autonomizada família. Família como figura central ou continente, de que tudo o mais é conteúdo. Imperiosidade da interpretação não-reducionista do conceito de família como instituição que também se forma por vias distintas do casamento civil. Avanço da Constituição Federal de 1988 no plano dos costumes. Caminhada na direção do pluralismo como categoria sócio-políticocultural. Competência do Supremo Tribunal Federal para manter, interpretativamente, o Texto Magno na posse do seu fundamental atributo da coerência, o que passa pela eliminação de preconceito quanto à orientação sexual das pessoas. 4. União estável. Normação constitucional referida a homem e mulher, mas, apenas para especial proteção desta última. Focado propósito constitucional de estabelecer relações jurídicas horizontais ou sem hierarquia entre as duas tipologias do gênero humano. Identidade constitucional dos conceitos de "entidade familiar" e "família". A referência constitucional à dualidade básica homem/mulher, no $\S 3^{\circ}$ do seu art. 226, deve-se ao centrado intuito de não se perder a menor oportunidade para favorecer relações jurídicas horizontais ou sem hierarquia no âmbito das sociedades domésticas. Reforço normativo a um mais eficiente combate à renitência patriarcal dos costumes brasileiros. Impossibilidade de uso da letra da Constituição para ressuscitar o art. 175 da Carta de 1967/1969. Não há como fazer rolar a cabeça do art. 226 no patíbulo do seu parágrafo terceiro. Dispositivo que, ao utilizar da terminologia "entidade familiar", não pretendeu diferenciá-la da "família". Inexistência de hierarquia ou diferença de qualidade jurídica entre as duas formas de constituição de um novo e autonomizado núcleo doméstico. Emprego do fraseado "entidade familiar" como sinônimo perfeito de família. A Constituição não interdita a formação de família por pessoas do mesmo sexo. Consagração do juízo de que não se proíbe nada a ninguém senão em face de um direito ou de proteção de um legítimo interesse de outrem, ou de toda a sociedade, o que não se dá na hipótese sub judice. Inexistência do direito dos indivíduos heteroafetivos à sua não-equiparação jurídica com os indivíduos homoafetivos. Aplicabilidade do $\$ 2^{\circ}$ do art. $5^{\circ}$ da Constituição Federal, a evidenciar que outros direitos e garantias, não expressamente listados na Constituição, emergem "do regime e dos princípios por ela adotados", verbis: "Os direitos e garantias expressos nesta Constituição não excluem outros decorrentes do regime e dos princípios por ela adotados, ou dos tratados internacionais em que a República Federativa do Brasil seja parte". 5. Divergências laterais quanto à fundamentação do acórdão. Anotação de que os Ministros Ricardo Lewandowski, Gilmar Mendes e Cezar Peluso convergiram no particular entendimento da impossibilidade de ortodoxo enquadramento da união homoafetiva nas espécies de família constitucionalmente estabelecidas. Sem embargo, reconheceram a união entre 
parceiros do mesmo sexo como uma nova forma de entidade familiar. Matéria aberta à conformação legislativa, sem prejuízo do reconhecimento da imediata autoaplicabilidade da Constituição. 6. Interpretação do art. 1.723 do Código Civil em conformidade com a Constituição Federal (técnica da "interpretação conforme"). Reconhecimento da união homoafetiva como família. Procedência das ações. Ante a possibilidade de interpretação em sentido preconceituoso ou discriminatório do art. 1.723 do Código Civil, não resolúvel à luz dele próprio, faz-se necessária a utilização da técnica de "interpretação conforme à Constituição". Isso para excluir do dispositivo em causa qualquer significado que impeça o reconhecimento da união contínua, pública e duradoura entre pessoas do mesmo sexo como família. Reconhecimento que é de ser feito segundo as mesmas regras e com as mesmas consequências da união estável heteroafetiva (Brasil. Ação Direta de Inconstitucionalidade 4277, 2011).

A partir dessa decisão, os homossexuais passaram a ter alguns direitos que outrora só eram garantidos à parcela heterossexual da população, tais como: direito de comunhão parcial de bens; direito à pensão alimentícia no caso de separação; direito a mencionar o parceiro como dependente ao declarar o Imposto de Renda; direito a adotar crianças, que era garantido, preferencialmente, a casais heterossexuais; e direitos relativos à previdência social. No que diz respeito aos efeitos e à abrangência dessa decisão, podemos dividir os votos em dois grupos distintos. Há o grupo majoritário, composto pelos Ministros Ayres Britto (relator), Luiz Fux, Cármen Lúcia, Joaquim Barbosa, Marco Aurélio e Celso de Mello, que conclui

(...) pela possibilidade da interpretação conforme o art.1723 do Código Civil e pela obrigatoriedade constitucional não apenas do reconhecimento das uniões homoafetivas como entidades familiares, mas também pela necessidade de que a sua disciplina normativa fosse a mesma conferida às uniões heteroafetivas, não havendo motivos a ensejar tratamento diferenciado. A conclusão, portanto, foi pela existência de uma mesma entidade familiar, a união estável, tanto para casais do mesmo sexo, quanto para casais de sexos diferentes. O texto normativo do $\S 3^{\circ}$ do art.226 da Constituição foi objeto de uma 'interpretação superadora da literalidade', nas palavras do Relator, para entender que a referência a 'homem e mulher' seria apenas um reforço à previsão de igualdade entre os gêneros na família (art. 226, $\S 5^{\circ}$ da Constituição) e no direito em geral (art.5 ${ }^{\circ}$ I da Constituição), não podendo o dispositivo de índole francamente emancipatória ser interpretado de forma a discriminar casais homoafetivos e reforçar preconceitos constitucionalmente rechaçados (CARDINALI, 2018, p. 130). 
Existe também a corrente minoritária em relação à decisão, que é composta pelos ministros Gilmar Mendes, Ricardo Lewandowski e Cezar Peluso:

(...) descabimento da interpretação conforme na medida em que o dispositivo do Código Civil apenas reproduziu o disposto no art.226, $\S 3^{\circ}$ da Constituição, não sendo próprio, portanto, em razão da literalidade do texto normativo constitucional, entender as uniões homoafetivas como uniões estáveis, devendo ser reconhecidas como outro tipo de entidade familiar, com base na não exaustividade do rol de entidades previstas nos parágrafos do art.226. todavia, diante da ausência de normas a regular esta modalidade de entidade familiar, deveria o STF por meio de interpretação analógica aplicarlhes o mesmo regramento, no que cabível, da entidade familiar mais assemelhada, no caso a união estável, convidando, ainda, o Congresso Nacional a editar lei disciplinando a entidade familiar homoafetiva (CARDINALI, 2018, p. 130-131).

Sendo assim, a união estável homoafetiva foi uma vitória considerável para a comunidade LGBT+. Todavia, trata-se de uma demanda do grupo menos excluído na comunidade, pois pessoas trans e travestis, por exemplo, continuam sendo menos aceitas socialmente do que pessoas homossexuais. $\mathrm{O}$ que se deve compreender é que entre as diversas demandas da comunidade, a união estável era uma das menos ousadas, ou seja, que teria menor índice de reprovação pela população e que era considerada plausível de ser reconhecida dentro de uma lógica de aceitação e conquista de direitos pela comunidade LGBT+. Ainda há diversos outros direitos a serem conquistados.

\subsection{Casamento igualitário}

Com a decisão favorável em relação à união estável homoafetiva, os casais gays começaram a reivindicar o direito de conversão dessa união estável em casamento. Todavia, muitos cartórios se negavam a realizar a conversão e, assim, em 2013, o Conselho Nacional de Justiça publicou a Resolução 175, que permite o registro do casamento entre pessoas do mesmo sexo pelos cartórios e impossibilita a recusa. 
A discussão acerca do tema é calorosa, havendo aqueles contrários ao reconhecimento da união estável homoafetiva, o que gerou a proposta de um Estatuto da Família com o intuito de reverter o entendimento que foi firmado pelo STF. Há também grupos que apoiam esse direito reconhecido, compostos, em sua maioria, pela comunidade LGBT+, e buscam a positivação desse entendimento tanto na seara da legislação ordinária quanto na própria Constituição, garantindo, assim, a manutenção do casamento igualitário.

A luta pelo casamento homoafetivo é muito forte dentro da comunidade LGBT+, que fundamenta o seu direito tanto no princípio da igualdade, exposto nesse trabalho, quanto também por se tratar de um imperativo de reconhecimento. Assim defende o ex-deputado Jean Wyllys:

A nossa luta pelo casamento, portanto, não aponta somente para a conquista desse direito: significa uma luta pelo reconhecimento social e político da dignidade das pessoas homossexuais. É porque também se trata de uma luta cultural e simbólica. Nos países onde o Estado reconheceu o casamento civil entre pessoas do mesmo sexo, as novas gerações crescem sabendo que gays e lésbicas não são melhores ou piores do que os heterossexuais, mas apenas diferentes, e que suas famílias valem, para o Estado e para a sociedade, tanto quanto as famílias heterossexuais, e merecem o mesmo respeito e reconhecimento (WYLLYS, 2014, p. 138 apud CARDINALI, 2018, p. 41).

\subsection{Criminalização da homofobia}

A criminalização da homofobia foi votada no Supremo Tribunal Federal e, por 8 votos a 3 , decidiu-se que as condutas preconceituosas relacionadas à orientação sexual se encontram enquadradas na Lei 7.716/1989, que pune o racismo.

Além disso, o STF entendeu que a criminalização da homofobia não invade a seara religiosa, fazendo com que os fieis possam pregar e divulgar as suas crenças livremente, de acordo com a liberdade religiosa prevista na Constituição. Isso se essas manifestações religiosas não incitarem discurso de ódio e nem violência contra a comunidade LGBT+. Um dos votos mais interessantes foi o da Ministra Cármen Lúcia, que expôs haver um "déficit 
legislativo inaceitável", defendendo que o STF tem o dever de corrigir esse erro, tutelando, assim, os direitos fundamentais e impedindo que a Constituição seja apenas um pedaço de papel, como tratado por Ferdinand Lassalle. Além disso, a Ministra tratou da questão das pessoas LGBT+ serem desprezadas como se nem humanas fossem e do fato de não haver espaço para um discurso no qual a identidade de um individuo seja usada como pretexto para desigualdade de direitos.

Dentro do próprio movimento há quem acredite que a criminalização não é a solução e defenda que outros mecanismos seriam mais efetivos ao enfrentamento e desconstrução do preconceito, tais como ações de conscientização e debates acerca da diversidade sexual e de identidade de gênero nas escolas. Assim, Borrillo entende que anterior à repressão da homofobia, é preciso uma atuação pedagógico-preventiva que modifique o jeito que a diversidade sexual é encarada socialmente, tendo a percepção que sem esta atuação a criminalização não teria sentido (BORRILLO, 2010, p. 106).

Acredito que realmente a criminalização não é a solução absoluta para todos os problemas de discriminação e preconceito sofridos pela comunidade LGBT+. Há outros mecanismos que devem ser pensados e utilizados, como defendido por Borrillo, em conjunto com a criminalização para que a comunidade galgue a igualdade em relação aos heterossexuais. A criminalização é o começo do caminho, mas ainda há muito a ser percorrido. 


\section{Direito à busca da felicidade}

\subsection{Breves apontamentos sobre felicidade na filosofia}

A filosofia contribuiu muito para o estudo sobre a felicidade ao longo dos anos. Entre os filósofos que estudaram o assunto e que não podemos esquecer ao tratar da felicidade estão Sócrates, Platão e Aristóteles. Para Sócrates, a felicidade é um bem soberano e determina o significado de vida boa. Segundo ele, a vida boa é a vida mais feliz e virtuosa. De acordo com a sua filosofia, a felicidade é, portanto, voltada para o conceito de virtude e afasta-se da noção de prazer. Conforme o seu pensamento, é impossível que um homem cruel seja feliz, ainda que ele sinta prazer. O gozo resultante de uma postura que acarretava prazer só poderia ser considerado felicidade a partir do momento em que estivesse atrelado à virtude. Caso contrário, seria qualquer coisa, menos felicidade. Além de estar ligada à virtude, a felicidade também está relacionada à justiça, pois, embora a satisfação dos desejos e as necessidades do corpo resultem prazer, nem todas as sensações permitidas corresponderão à felicidade, pois sua conduta pessoal também deverá ser justa e virtuosa.

Platão perpetua de certa forma os ensinamentos de Sócrates, visto que ele persegue a verdadeira virtude, que diria respeito à felicidade ser fundada no "autocontrole, na disciplina, na abnegação e no desvio quanto aos excessos, mesmo que prazerosos" (LEAL, 2013, p.18). Além disso, o pensamento do filósofo traz à tona a ideia de uma felicidade coletiva e outra individual, que seriam distintas, mas deveriam coexistir em uma cidade-estado.

Aristóteles também trata da felicidade atrelada a se ter uma vida virtuosa, mas esta só seria atingida por meio da atividade, ou seja, a pessoa teria a necessidade de conquistar bens tanto espirituais quanto materiais. Assim, com base no pensamento do filósofo, a felicidade seria autossuficiente, 
um fim em si mesmo, não sendo considerada um meio para atingir os seus resultados.

\subsection{Características e importância}

Derivado da felicidade tão estudada pelos filósofos há, nos dias atuais, o direito à busca da felicidade, que diz respeito ao direito que cada indivíduo tem de perseguir seus desejos e preferências legítimas sem a intervenção por parte do Estado ou de particulares. Caso um destes queira intervir nesse direito, deve fundamentar o motivo, pois se caracteriza um obstáculo a uma forma de liberdade, que é a liberdade de buscar realizar a própria felicidade.

Adam Smith é o primeiro a falar sobre esse direito ao tratar do dever do Estado e impedir que as pessoas devastem mutuamente os direitos recíprocos de busca da felicidade desfrutados por cada indivíduo. A ideia proposta pelo filósofo se materializa no Preâmbulo da nossa Constituição, quando este afirma que o Estado Democrático brasileiro tem como dever assegurar o exercício dos direitos sociais e individuais, a liberdade, a segurança, o bem-estar, a igualdade e a justiça como valores imperativos de uma sociedade fraterna, pluralista e sem preconceitos. Com base nisso, fica fácil a percepção de que o projeto do constitucionalismo contemporâneo brasileiro é um projeto de felicidade para todos.

Mesmo sendo tão importante, a busca da felicidade deve ter restrições, de acordo com Leal (2013), se ao buscar a felicidade se acabe por ferir o princípio da dignidade da pessoa humana. Assim, uma decisão que leve em consideração os prováveis efeitos que ela gerará na felicidade das pessoas envolvidas pode causar injustiças a um ou outro indivíduo isolado. Por conta disso, não é aceitável que haja o sacrifício dos direitos de alguns para que outros alcancem os seus. Quando a aplicação do direito à busca da felicidade coloca em risco direitos individuais, independente do saldo positivo quanto à utilidade da decisão, se esse saldo ocorrer às custas de ofensa à dignidade, não 
há como defendê-lo.

Decorrente do direito à busca da felicidade está o direito à felicidade, que é o direito que cada indivíduo tem de ser amparado pelo Estado através de iniciativas que o ajudem a concretizar seus desejos de felicidade. Dessa forma, quando se trata do direito à felicidade, o Estado deve atuar fornecendo os instrumentos necessários para que as pessoas alcancem os seus almejados projetos de felicidade. Segundo Robert Alexy (ALEXY, 2008, p. 64 apud LEAL, 2013, p. 205), o direito à felicidade deve ser considerado como um princípio, que por simbolizar aspirações de liberdade, segurança e igualdade, constitui um princípio inserido no rol dos direitos fundamentais.

O direito à busca da felicidade pode ser compreendido também como sendo a concretização de todos os direitos individuais e coletivos. A felicidade, pensada como exercício do próprio direito, resultaria, naturalmente, da tutela dos demais direitos. Esse direito só pode, sob essa lógica, ser concretizado se os demais direitos forem satisfeitos, como o direito à vida, à saúde, à alimentação, à moradia, à educação, ao trabalho, entre outros. Assim, para que haja felicidade individual, é preciso que uma felicidade coletiva seja observada, ou seja, que os direitos sociais previstos no nosso texto constitucional sejam assegurados.

\subsection{Previsão e efeitos na comunidade LGBT+}

A Constituição Federal Brasileira de 1988 não traz em seu texto, expressamente, o direito à busca da felicidade. Entretanto, já houve tentativa de tornar o Estado garantidor de condições para a efetivação deste direito por meio de uma previsão constitucional explícita.

No ano de 2010, o Senador Cristovam Buarque elaborou a Proposta de Emenda à Constituição no 19/2010 - conhecida como PEC da Felicidade -, com o objetivo de alterar o artigo $6^{\circ}$ da Constituição para incluir, junto aos 
direitos sociais ali previstos, a busca da felicidade como razão maior para a concretização daqueles direitos. Dispôs a Ementa da PEC 19/2010:

Altera o artigo $6^{\circ}$ da Constituição Federal para incluir o direito à busca da Felicidade por cada indivíduo e pela sociedade, mediante a dotação pelo Estado e pela própria sociedade das adequadas condições de exercício desse direito (PEC 19/2010. Brasília, Julho de 2010.Disponível em: <https://www25.senado.leg.br/ web/atividade/materias//materia/97622.>. Acesso em 10 nov/2019).

Dessa forma, de acordo com o texto inicial da Proposta de Emenda à Constituição n 19/2010, o artigo $6^{\circ}$ da CRFB/88 teria a seguinte redação:

Art. $6^{\circ}$. São direitos sociais, essenciais à busca da felicidade, a educação, a saúde, a alimentação, o trabalho, a moradia, o lazer, a segurança, a previdência social, a proteção à maternidade e à infância, a assistência aos desamparados, na forma desta Constituição.

Para justificar essa mudança, utilizou-se o raciocínio de que a previsão expressa do direito de o indivíduo buscar a felicidade pressupunha a observância da felicidade coletiva. Nesse sentido, afirma o texto da Proposta que:

Há felicidade coletiva quando são adequadamente observados os itens que tornam mais feliz a sociedade, ou seja, justamente os direitos sociais - uma sociedade mais feliz é uma sociedade mais bem desenvolvida, em que todos tenham acesso aos básicos serviços públicos de saúde, educação, previdência social, cultura, lazer, dentre outros (PEC 19/2010. Brasília, Julho de 2010. Disponível em: <https://www25.senado.leg.br/ web/atividade/materias//materia/97622.>. Acesso em 10 nov/2019).

Contudo, é necessário informar que, apesar de a Proposta do Senador Cristovam Buarque ter tido, inicialmente, parecer favorável e assinatura de diversos membros do Senado, foi arquivada em dezembro de 2014, devido à mudança de Legislatura, nos termos do artigo 332 do Regimento Interno do Senado Federal e do Ato da Mesa nº 2, de 2014. 
Proposta de Emenda à Constituição no 513/2010 - de mesmo teor e visando a mesma alteração - foi apresentada em agosto de 2010, tendo sido arquivada nos termos do artigo 105 do Regimento Interno da Câmara dos Deputados em janeiro de 2011. Foi solicitado o seu desarquivamento, retornando em fevereiro do mesmo ano à tramitação. Todavia, em janeiro de 2015 a referida Proposta foi novamente arquivada, nos mesmos termos do artigo supracitado.

Dessa forma, as Propostas para formalização do direito à busca da felicidade no texto constitucional encontram-se arquivadas. Entretanto, o tema continua sendo objeto de reflexão e os debates atuais estão focados, principalmente, no fato de os direitos fundamentais convergirem para a felicidade.

Mesmo sem a palavra felicidade prevista no texto constitucional, Saul Tourinho Leal defende que a Constituição

ampara o direito à felicidade explicitamente, quando trata do bem-estar e, implicitamente, quando possibilita que ele ingresse no ordenamento jurídico brasileiro aliado a outros dispositivos constitucionais, como o direito à liberdade (direito à busca da felicidade) ou o direto à saúde (direito prestacional à felicidade) (LEAL, 2014, p. 184).

Podemos invocar o $\S 2^{\circ}$ do artigo $5^{\circ}$ da Constituição, mesmo que não se utilize essa lógica proposta por Leal para defender a presença da felicidade em nossa Constituição. Todavia, não é necessário que este parágrafo seja usado, visto que temos apenas que atentar ao Preâmbulo da Carta, que é observado das mais diversas formas no corpo do documento. Assim, a Constituição ao tratar do exercício dos direitos sociais e individuais, a liberdade, a segurança, o bem-estar, o desenvolvimento, a igualdade e a justiça, requer respeito à felicidade.

O princípio da busca da felicidade, ainda que seja um princípio utilizado recentemente pela nossa jurisprudência, foi importante no julgamento da Ação 
de Descumprimento de Preceito Fundamental 132 em conjunto com a Ação Direta de Inconstitucionalidade 4277 para justificar a decisão que afirmou a obrigatoriedade do reconhecimento do status de entidade familiar aos casais homoafetivos em regime de união estável. Além disso, essa decisão garantiu à comunidade LGBT+ os mesmo direitos e deveres dos companheiros em união estável heteroafetiva, desde que estejam presentes os mesmos pressupostos de reconhecimento desta última modalidade de união estável. O princípio encontra-se explícito na ementa da decisão:

Reconhecimento do direito à preferência sexual como direta emanação do princípio da 'dignidade da pessoa humana': direito a autoestima no mais elevado ponto da consciência do indivíduo. Direito à busca da felicidade. Salto normativo da proibição do preconceito para a proclamação do direito à liberdade sexual (Brasil. Ação Direta de Inconstitucionalidade 4277, 2011).

O Ministro Celso de Mello ao tratar do princípio da busca da felicidade no julgamento da ADPF 132 afirma a sua importância e entende ser ele corolário da dignidade da pessoa humana. Com base nisso afirma:

O postulado constitucional da busca da felicidade, que decorre, por implicitude, do núcleo de que se irradia do princípio da dignidade da pessoa humana, assume papel de extremo relevo no processo de afirmação, gozo e expansão dos direitos fundamentais, qualificando-se, em função de sua própria teleologia, como fator de neutralização de práticas ou de omissões lesivas cuja ocorrência possa comprometer, afetar ou, até mesmo, esterilizar direitos e franquias individuais. (BRASIL, Supremo Tribunal Federal. Ação de Descumprimento de Preceito Fundamental 132 Rio de Janeiro. Voto do Ministro Celso de Mello).

Além da ementa da ADI 4277, encontra-se explícito o direito à busca da felicidade no voto do Ministro Celso de Melo no julgamento da Ação Direta de Inconstitucionalidade por Omissão 26 , que trata da criminalização da homofobia. 
Esta decisão - que torna efetivo o princípio da igualdade, que assegura respeito à liberdade pessoal e à autonomia individual, que confere primazia à dignidade da pessoa humana e que, rompendo paradigmas históricos e culturais, remove obstáculos que inviabilizam a busca da felicidade por parte de transgêneros vítimas de inaceitável tratamento discriminatório - não é nem pode ser qualificada como decisão proferida contra alguém, da mesma forma que não pode ser considerada um julgamento a favor de apenas alguns, mas, sim, de toda a coletividade social. (Brasil. Ação Direta de Inconstitucionalidade por Omissão 26, 2019).

O direito à busca da felicidade deve ser eficaz para assegurar o direito das minorias, pois o Estado não tem o condão de interferir discricionariamente nas vontades e desejos das pessoas. Sob essa lógica, não existem motivos para que diversas demandas da comunidade LGBT+ sejam negadas e, por isso, nos últimos anos o movimento LGBT+ tem conquistado alguns direitos que outrora pareciam impossíveis, como a união estável homoafetiva, a criminalização da homofobia, o casamento igualitário e a possibilidade por parte das pessoas trans de alterarem o seu registro civil sem a necessidade de realizar a cirurgia de redesignação sexual. Assim, o reconhecimento do direito à busca da felicidade foi essencial para a garantia desses direitos, assim como os que lhes são correlatos, como os previdenciários ao parceiro que sobrevive, afastando-se a sórdida discriminação de gênero ou por orientação sexual. A partir disso, torna-se imprescindível que o Estado impeça qualquer discriminação atentatória aos direitos e liberdades fundamentais. 


\section{Ações afirmativas}

\subsection{Breve abertura: noções e conceito}

As políticas de ação afirmativa surgiram, em primeiro lugar, nos Estados Unidos, sendo utilizadas especialmente pela Suprema Corte. Funcionam como uma forma de comprometer organizações tanto públicas quanto privadas com a efetividade do princípio da igualdade por meio do favorecimento de grupos marginalizados e discriminados, podendo ser estes compostos por pessoas físicas ou jurídicas. Dessa forma, a sociedade se torna menos desigual, favorecendo, ainda, o Estado Democrático de Direito, visto que torna mais efetiva a representatividade da população, na medida em que as minorias se tornam abrangidas pelo princípio da igualdade, tão importante no nosso texto constitucional.

Uma definição sucinta e bem feita do que são as ações afirmativas é realizada por Joaquim B. Barbosa Gomes:

As ações afirmativas podem ser definidas como um conjunto de políticas públicas e privadas de caráter compulsório, facultativo ou voluntário, concebidas com vistas ao combate à discriminação, (...) bem como para corrigir os efeitos presentes da discriminação praticada no passado, tendo por objetivo a concretização do ideal de efetiva igualdade de acesso a bens fundamentais como a educação e o emprego (GOMES, 2001, p. 40).

Ao tomar consciência sobre os grupos marginalizados $\mathrm{e}$ as discriminações por estes sofridas, o legislador cria medidas de incentivo e favorecimento para eles, com o intuito de que estes consigam alcançar posições igualitárias na sociedade. Um dos instrumentos utilizados para se chegar a isso é a adoção de políticas de ação afirmativa. Sales Augusto dos Santos defende que as ações afirmativas não possuem um caráter discriminatório, e sim que servem como uma forma de garantia de um tratamento mais igualitário no presente, com a intenção de compensar a discriminação sofrida no passado. 
Ação afirmativa é tratar de forma preferencial aqueles que historicamente foram marginalizados, para que lhes sejam concedidas condições equidistantes aos privilegiados da exclusão. Diferencia-se drasticamente da redistribuição, já que não é simples busca de diminuição de carência econômica, mas, sim, uma medida de justiça, tendo por base injustas considerações históricas que erroneamente reconheceram e menosprezaram a identidade desses grupos discriminados (SANTOS, 2005, p. 45-46).

Em relação a essas políticas é imprescindível tratar-se dos artigos $1^{\circ}$ e $3^{\circ}$ da Constituição, visto que aquele revela os fundamentos da República, entre eles a cidadania e a dignidade da pessoa humana, enquanto este especifica os objetivos da nossa República: construir uma sociedade livre, justa e solidária; erradicar a pobreza e a marginalização e reduzir as desigualdades sociais e regionais; promover o bem de todos sem preconceito de origem, raça, sexo, cor, idade e quaisquer outras formas de discriminação. O Ministro Marco Aurélio de Melo defende que se presume uma posição ativa por parte do Estado em relação ao alcance desses objetivos ao analisarmos os verbos usados pelo legislador no artigo $3^{\circ}$ da nossa Constituição.

Do artigo $3^{\circ}$ vem-nos luz suficiente ao agasalho de uma ação afirmativa, a percepção de que o único modo de se corrigir desigualdades é colocar o peso da lei, com a imperatividade que ela deve ter em um mercado desequilibrado, a favor daquele que é discriminado, que é tratado de forma desigual. Nesse preceito são considerados como objetivos fundamentais de nossa República: primeiro, construir - prestem atenção a esse verbo - uma sociedade livre, justa e solidária; segundo, garantir o desenvolvimento nacional - novamente temos aqui o verbo a conduzir, não a uma atitude simplesmente estática, mas a uma posição ativa; erradicar a pobreza e a marginalização e reduzir as desigualdades sociais e regionais; e, por último, no que nos interessa, promover o bem de todos, sem preconceitos de origem, raça, sexo, cor, idade e quaisquer outras formas de discriminação. Posso asseverar, sem receio e equívoco, que se passou de uma igualização estática, meramente negativa, no que se proibia a discriminação, para uma igualização eficaz, dinâmica, já que os verbos "construir", "garantir", "erradicar" e "promover" implicam, em si, mudança de óptica, ao denotar "ação". É preciso viabilizar - e encontramos na Carta da República, base para fazê-lo - as mesmas oportunidades. Há de ter-se como página virada o sistema simplesmente principiológico. A postura deve ser, acima de tudo, afirmativa. E é necessário que essa seja a posição adotada pelos nossos legisladores (MELLO, 2001. Disponível em: $<$ http://www.stf.jus.br/portal/cms/verNoticiaDetalhe.asp?idConteudo=10006 9\&sigServico=noticiaArtigoDiscurso>. Acesso em 26 out. 2019). 
Com base no cenário no qual está inserida a sociedade brasileira, ou seja, a perpetuação das discriminações, como, por exemplo, em relação à comunidade LGBT+, sem haver um arcabouço de proteção jurídica a essas parcelas marginalizadas da sociedade, faz-se imprescindível a combinação da proibição dessa discriminação com políticas compensatórias que acelerem a igualdade, assim como estratégias promocionais apropriadas a estimular a inserção e a inclusão desses grupos socialmente vulneráveis nos espaços sociais. Com isso tende-se a remediar um passado discriminatório, pois mesmo estando presentes na Constituição os princípios da dignidade da pessoa humana e da igualdade, existem muitas pessoas que continuam sem acesso a oportunidades mínimas de emprego, participação política e cidadania.

As ações afirmativas não são pautadas apenas pelo fim de equalização social, pois elas servem também para estimular transformações de ordem cultural e psicológica que façam com que as pessoas parem de acreditar que há uma relação tanto de supremacia quanto de subordinação entre elas. Sendo assim, essas políticas auxiliam na implementação dos ideais de igualdade material e justiça, que demandam, simultaneamente, redistribuição e reconhecimento de identidades, possibilitando que haja igualdade social e respeito à diversidade.

Luciana Dayoub trata da estruturação normativa que uma ação afirmativa deve ter:

A estruturação normativa de uma ação afirmativa deve pautar-se, inicialmente, na regra de objetividade, que se dirige à identificação do grupo desfavorecido que será alvo da norma, o qual deve ser objetivamente determinado, obstando a utilização de conceitos imprecisos, mesmo porque a distinção estabelecida deve basear-se em desigualdades reais e objetivas entre as pessoas e circunstancias. Em seguida, há de ser observada a regra de proporcionalidade, pela qual se define a amplitude do avantajamento que se visa a deferir, de forma que o favorecimento seja proporcional à desigualdade a ser corrigida. E, além disso, esse avantajamento, conforme a regra de adequação deve ser idôneo, adequado à correção objetivada. Sob pena de caracterizar privilégio ou discriminação ilegítima, necessário reger-se a 
norma da ação afirmativa, ainda, pela regra de finalidade, ou seja, pautar-se, estritamente, na correção de desigualdades sociais (ALMEIDA, 2011, p. 66$67)$.

Essa estruturação é importante para que haja a análise e a percepção de que o valor a ser promovido com a falta de equiparação tem que ser mais relevante do que aquele que está sendo sacrificado. Com base nisso é que se tira a conclusão de que os meios usados para alcançar a finalidade desejada pela ação afirmativa não podem ser um obstáculo intransponível para aqueles que não se encontram beneficiados pela política em tela.

A política das ações afirmativas deve ser válida até o momento da correção da desigualdade e, assim, é possível extrair a condição jurídica de que essa política deve ser afastada no momento que não houver mais a desigualdade a qual ela se propunha eliminar. Dessa forma, devem ser instituídas com uma delimitação temporal, tendo por fundamento primordial a eliminação de uma situação pontual e inequívoca de discriminação. Entretanto, enquanto não sanadas as discriminações, as ações afirmativas detêm legitimidade para permanecer vigentes, protraindo-se no tempo, salvo no caso delas não se encontrarem mais adequadas para as situações discriminatórias que lhe deram existência. Além disso, a regra da temporariedade pode ser excepcionada, segundo Luciana Dayoub (2011), ao se utilizar o entendimento segundo o qual por se tratar de uma cláusula constitucional encontra-se ligada a direito fundamental e, portanto, protegida pela característica da imutabilidade que é definidora das cláusulas pétreas, previstas no artigo $60, \S 4^{\circ}$, inciso IV da Constituição.

\subsection{Panorama das ações afirmativas para a comunidade LGBT+}

As ações afirmativas tratam de políticas voltadas a pessoas pertencentes a grupos discriminados pela exclusão socioeconômica tanto no presente quanto 
no passado. Para ajudar essas pessoas utilizam-se os princípios da dignidade da pessoa humana e da igualdade e são alocados recursos tanto por organizações públicas quanto privadas. O enfoque desse trabalho é nas ações afirmativas direcionadas à comunidade LGBT+e, dessa forma, é de suma importância que algumas delas sejam especificadas a seguir.

Muitos autores tratam especificamente de algumas ideias de políticas públicas propícias à comunidade LGBT+, sendo elas: a alteração do nome e do sexo no registro civil dos transexuais; cirurgia genital para transexuais; acesso ao emprego por meio de programas de capacitação; não necessidade de testemunha para abertura de processo por discriminação; criação de conselhos de medicina e psicologia e equipes de apoio às pessoas com desvios sexuais; concessão de incentivo fiscal para quem empregar travestis; tratamento diferenciado nas contratações do setor público; introdução de disciplinas contra o preconceito nos currículos escolares; e controle social da televisão, do cinema, das charges, do teatro, para evitar piadas que estimulem a violência contra homossexuais.

\subsubsection{Demandas de pessoas trans}

Dentro das ações afirmativas voltadas à comunidade LGBT+, considero importante destacar as que têm por enfoque a última sigla do "LGBT", que representa um grupo gigante de pessoas e identidades as quais baseiam suas demandas em uma identidade de gênero não cisgênera, visto que não se identificam com a identidade de gênero que thes foi designada no nascimento. Em relação às outras letras da sigla, elas compartilham uma orientação sexual não heterossexual. Segundo Mario Felipe de Lima Carvalho (CARVALHO, 2011, p. 47 apud CARDINALI, 2018, p. 44), são três as principais demandas deste grupo, sendo elas: a possibilidade de alteração do registro civil no que diz respeito ao nome e ao sexo; direito a transformações corporais por meio do 
SUS, tais como terapia hormonal e cirurgia de transgenitalização; e a luta pela despatologização.

Em relação à questão da alteração do registro civil, há outra demanda dessa parcela da comunidade LGBT+ que se coloca de forma precípua, que é a possibilidade de uso do nome social, que se trata do prenome com o qual a pessoa se identifica e se apresenta perante a sociedade. O nome social já é reconhecido por variadas instituições e instâncias. Atrelada à possibilidade de utilização do nome social encontra-se a luta das pessoas trans em poder se apresentar socialmente nas instituições de acordo com o seu gênero de identificação, por exemplo, através do uso de uniformes e banheiros adequados.

Essa demanda foi julgada pelo STF, na ADI 4275, que autorizou a alteração do nome social e o gênero em documentos de transgêneros mesmo sem terem realizado a cirurgia de transgenitalização ou terem realizado tratamento hormonal. É um grande avanço porque a pessoa vai precisar somente ir a um cartório e declarar seu novo nome, sem haver a necessidade, portanto, de entrar na justiça para pedir a alteração. Conforme a decisão, o cartório não precisa expedir uma nova certidão de nascimento para transexuais, modificando os dados no documento que já existe, sendo que essa mudança permanece em sigilo no próprio cartório. Esse julgamento é de suma importância por demonstrar que o STF está julgando as demandas de transgêneros com base no princípio da igualdade, ou seja, no sentido do não preconceito.

Mario Felipe, ao tratar da segunda bandeira de maior relevância deste grupo, diz que se trata do acesso aos serviços de saúde, com o custeio do processo transexualizador pelo SUS, na seara da qual se inclui a cirurgia de transgenitalização. 
Atualmente, este procedimento é realizado em quatro hospitais no Brasil, porém está condicionado à obtenção de diagnóstico de Transtorno de Identidade de Gênero - TIG, o que reforça uma lógica de patologização da transexualidade. Este processo é conduzido pelo saber médico e psicológico e muitas vezes oferece um único roteiro identitário, que exclui transexuais que não pretendem se submeter à transgenitalização, travestis e identidades de gênero não-binárias (CARVALHO, 2011, p. 118 apud CARDINALI, 2018, p. 45-46).

Por fim, existe a demanda da despatologização. Porém, essa é muito forte no movimento LGBT+ internacional, tendo menor força no Brasil. Isso porque o acesso a direitos e políticas de saúde é realizado tendo por base a categoria patologizante de Transtorno de Identidade de Gênero e, assim, há temor por parte de pessoas trans e travestis no Brasil que a despatologização dessa vivência possa vir a eliminar as políticas públicas voltadas para essa parcela da população (CARVALHO, 2011, p. 120 apud CARDINALI, 2018, p. 46).

A parcela da comunidade LGBT+, representada pelo "T" da sigla, é a que mais sofre com preconceito e discriminação, às vezes até mesmo dentro da própria comunidade homossexual. Isso faz com que as pessoas trans e travestis apresentem muitas dificuldades para permanecer nas escolas, resultando em um nível baixo de escolaridade dessa população, assim como para ingressar no mercado formal de trabalho, o que leva, em grande parte dos casos, mulheres transexuais e travestis a se prostituírem. Além disso, as pessoas transgênero são regularmente vítimas de violência, muitas vezes fatal. Por tudo isso, é essencial a aplicação de políticas de ações afirmativas voltadas à comunidade LGBT+, sobretudo direcionadas à parcela que compõe a letra "T" da sigla que representa o movimento. 


\section{Considerações Finais}

Em virtude do delicado momento político em que estamos inseridos no momento, falar sobre felicidade pode parecer, para alguns, um assunto pífio. Com as eleições ocorridas no ano passado (2018), e Jair Bolsonaro como Presidente da República, estamos vivenciando um momento de difícil progresso nas demandas e vontades da população LGBT+. O nosso presidente é explicitamente homofóbico e não perde a oportunidade de discriminar e desmerecer a comunidade LGBT+ e suas conquistas. Em meio a essa turbulência que estamos vivendo, pode parecer ilógico que se pense em direito à busca da felicidade, ainda mais se ela estiver referida a homossexuais, trans e travestis. Contudo, é exatamente por estarmos em um momento contrário às demandas LGBT+ que precisamos ir à luta pelos nossos direitos, principalmente à igualdade, dignidade da pessoa humana e, sem sombra de dúvidas, à busca da felicidade.

O direito à busca da felicidade não está previsto na nossa Constituição, como tratado ao longo desse trabalho. Todavia, encontra-se implícito como um princípio a ser seguido e assegurado a todos, independentemente de sua orientação sexual. Há quem acredite que não há espaço, atualmente, para se discutir e assegurar esse direito que nem está previsto em nosso texto constitucional. Assim, acreditam que aqueles direitos já constitucionalmente assegurados devem ser garantidos de forma eficaz pelo Estado, como os previstos nos artigos $5^{\circ}$ e $6^{\circ}$ da Constituição. Entretanto, defendo que estes direitos devem ser efetivamente assegurados, mas há espaço para o direito à busca da felicidade se somar àqueles e também ser garantido a todos.

Uma forma de garantia do direito à busca da felicidade no âmbito LGBT+ pelo Estado é por meio das ações afirmativas, que devem ser realizadas com o intuito de possibilitar que haja igualdade material entre homossexuais e heterossexuais, o que torne mais efetivo o princípio da 
dignidade da pessoa humana. Algumas políticas públicas para a comunidade LGBT+ já existem. No entanto, é apenas o começo, visto que há um caminho muito longo a se percorrer para que as diversas demandas LGBT+ sejam aceitas. Exatamente por isso que devemos continuar empunhando a bandeira e lutando por nossos direitos, tendo como cerne o nosso direito de ser feliz.

O presente trabalho procurou mostrar que o movimento LGBT+ brasileiro é recente, mas que ele vem somando vitórias ao longo dos últimos 50 anos. Conseguimos o direito à união homoafetiva, ao casamento igualitário e à criminalização da homofobia, o que demonstra que demandas que pareciam impossíveis há poucas décadas foram aceitas. Contudo, é importante perceber que a sigla LGBT+ é composta por diversas letras e que não é suficiente que apenas as vontades da maior parte dessa comunidade sejam acatadas, devendo todos que fazem parte dessa população lutar pelos direitos das parcelas mais estigmatizadas, como trans e travestis. $\mathrm{O}$ pensamento deve ser esse porque a comunidade LGBT+ é muito plural e diversificada e é importante que todos que a compõem desejem a felicidade de todos e juntem forças para obtê-la.

É um alento à alma a noção de que nunca tivemos tantos julgados - e ilustres julgadores - manifestando expressamente a importância desse direito, assim como a utilização deste para as decisões que tratam de demandas da comunidade LGBT+. Isso demonstra que mesmo estando em um momento contrário às reivindicações dessa comunidade, os julgadores são, em muitos casos, nossos apoiadores e desejam uma sociedade mais justa e igualitária, na qual os direitos sejam efetivamente para todos sem discriminação.

$\mathrm{O}$ direito à busca da felicidade foi elevado ao patamar de direito fundamental, mas isso não faz com que ele seja realmente seguido e assegurado pelo Estado. Somente quando este considerar a devida importância desse direito e possibilitar que a felicidade seja alcançada por qualquer pessoa, independentemente da sua orientação sexual, é que poderemos pensar em 
indivíduos mais felizes e na nossa sociedade mais justa e igualitária. Até que cheguemos a esse ponto, devemos continuar escrevendo, discutindo, lutando. 


\section{Referências Bibliográficas}

ALEXY, Robert. Constitucionalismo discursivo. Tradução Luís Afonso Heck. Porto Alegre: Livraria do Advogado Editora, 2008.

. Teoria dos direitos fundamentais. Tradução de Virgílio Afonso da Silva. São Paulo: Malheiros, 2008. 624 p.

ALMEIDA, Luciana Dayoub Ranieri de. Ações afirmativas e a concretização do princípio da igualdade no direito brasileiro. Belo Horizonte: Editora Fórum, 2011. 116 p.

BANDEIRA DE MELLO, Celso Antônio. O conteúdo jurídico do princípio da igualdade. $3^{\text {a }}$ edição. São Paulo: Malheiros, 2004. 48 p.

. Curso de Direito Administrativo. $20^{\mathrm{a}}$ edição. São Paulo: Malheiros, 2005. 1179 p.

BARCELlOS, Ana Paula de. A eficácia jurídica dos princípios constitucionais: o princípio da dignidade humana. $3^{\text {a }}$ edição. Rio de Janeiro: Renovar, 2011. 378 p.

BARROSO, Luís Roberto. Interpretação e aplicação da Constituição. $6^{a}$ edição. São Paulo: Saraiva, 2004. 427 p. 
BORRILLO, Daniel. Homofobia: história e crítica de um preconceito. Belo Horizonte: Autêntica, 2010. 142 p.

CARDINALLI, Daniel Carvalho. A judicialização dos direitos LGBT no STF: limites, possibilidades e consequências. Belo Horizonte: Arraes editores, 2018. $242 \mathrm{p}$.

CARVALHO, Mario Felipe de Lima. Que mulher é essa?: identidade, política e saúde no movimento de travestis e transexuais. 2011. 147 p. Dissertação de Mestrado. Programa de Pós-Graduação em Saúde Coletiva da Universidade Estadual do Rio de Janeiro - UERJ.

CASTELLS, Manuel. $O$ poder da identidade. $8^{a}$ edição. São Paulo: Paz e Terra, 1999. $530 \mathrm{p}$.

COMPARATO, Fábio Konder. A afirmação histórica dos direitos humanos. $3^{\mathrm{a}}$ edição. São Paulo: Saraiva, 2003. 577 p.

FACCHINI, Regina. Sopa de Letrinhas?: Movimento homossexual e produção de identidades coletivas nos anos 90. São Paulo: Garamond Universitária, 2005. 304 p.

FRASER, Nancy. Social Justice in the Age of Identity Politics: Redistribution, Recognition, and Participation. In: Fraser, Nancy. HONNETH, Axel. Redistribution or Recognition?: a political-philosophical exchange. Londres: Verso, 2004. 
GOMES, Joaquim B. Barbosa. A recepção do instituto da ação afirmativa pelo direito constitucional brasileiro. Revista de Informação Legislativa. Brasília, $\mathrm{n}$. 151, p. 129-152, jul./set. 2001. 24 p.

Ação afirmativa e princípio constitucional da igualdade. Rio de Janeiro: Renovar, 2001. 444 p.

HESSE, Konrad. A força normativa da Constituição. Tradução de Gilmar Ferreira Mendes. Porto Alegre: Sergio Antonio Fabris Editor, 1991. 34 p.

LEAL, Saul Tourinho. Direito à Felicidade: História, Teoria, Positivação e Jurisdição. São Paulo. 2013. 357 p. Tese (Doutorado em Direito Constitucional) Departamento de Direito da PUC - São Paulo.

MATTOS, Fernando da Silva. Direitos Fundamentais da população LGBT e o seu reconhecimento judicial. Disponível em: <http://www.direito.mppr.mp.br/arquivos/File/direitoslgbt_1.pdf>. Acesso em 22 out. 2019.

MELLO, Marco Aurélio de. Discriminação e Sistema Legal Brasileiro. Brasília: Tribunal Superior do Trabalho, 20 out. 2001. Palestra do ministro do Supremo Tribunal Federal aos ministros do TST. 2001. Disponível em: $<$ http://www.stf.jus.br/portal/cms/verNoticiaDetalhe.asp?idConteudo=100069 \&sigServico=noticiaArtigoDiscurso >. Acesso em 26 out. 2019. 
PEC 19/2010. Brasília, Julho de 2010. Disponível em: <https://www25.senado.leg.br/web/atividade/materias/-/materia/97622.>. Acesso em 10 nov. 2019.

ROCHA, Cármen Lúcia Antunes. Ação afirmativa: o conteúdo democrático do princípio da igualdade jurídica. Revista Trimestral de Direito Público, São Paulo, n. 15, p. 85-99, 1996. 13 p.

SANTOS, Sales Augusto dos. Ações Afirmativas e Combate ao Racismo nas Américas. Brasília: Ministério da Educação: UNESCO, 2005. 394 p.

SARLET, Ingo Wolfgang. A eficácia dos direitos fundamentais: uma teoria geral dos direitos fundamentais na perspectiva constitucional. $11^{\mathrm{a}}$ edição. Porto Alegre: Livraria do Advogado Editora, 2012. 504 p.

STF, ADI n. 4277. Rel. Ayres Britto, Brasília, 5 mai. 2011.

STF, ADPF 132. Rel. Ayres Britto, Brasília, 5 mai. 2011.

WYLLYS, Jean. Tempo Bom, Tempo Ruim: identidades, políticas e afetos. São Paulo: Paralela, 2014. 189 p. 